\title{
Belirli Süreli İş Sözleşmesinin Yapılması ve Yenilenmesinde Objektif Neden Koşulunun Değerlendirilmesi
}

\author{
Canan Ünal Adınır ${ }^{*}$ (]
}

Öz

İş sözleşmeleri belirli veya belirsiz süreli olarak yapılabilmekle birlikte hukukumuzda belirsiz süreli iş sözleşmesi kural, belirli süreli iş sözleşmesi ise istisnadır. İ̧̧ Kanunu m. 11/1 hükmü uyarınca belirli süreli iş sözleşmesi, belirli süreli işlerde veya belli bir işin tamamlanması veya belirli bir olgunun ortaya çıkması gibi objektif nedene bağlı olarak yapılabilir. Diğer iş kanunlarında benzer bir düzenlemeye yer verilmemiş olup bunun da sonucunda belirli süreli iş sözleşmesinin yapılması bakımından en kat kanun iş̧ Kanunu m. 11 hükmü doktrinde eleştirilere konu olmuştur. Aynı madde hükmünün 2 ve 3. fikralarında ise, belirli süreli iş sözleşmesinin yenilenmesi objektif neden koşuluna bağlanmıştır. Benzer bir düzenlemeye ise Türk Borçlar Kanunu m. 430 hükmünde yer verilmiştir. Dolayısıyla belirli süreli iş sözleşmesinin ilk defa yapılmasından farklı olarak yenilenmesinde iş kanunları arasında önemli bir farklııı bulunmamaktadır. Bu makalede, objektif nedenin ne anlama geldiği ve koşulun yerindeliği tartş̧ılacaktır. Bu bağlamda, İş Kanunu m. 11 hükmü ile belirli süreli iş sözleşmelerinin ilk defa yapılmasında aranan objektif neden koşuluna yönelik doktrindeki tartışmalar ve kanun çalışmaları değerlendirilecek olup objektif neden koşulu için nasıl bir istisna getirilebileceği ve de getirilmemesi gerektiği açıklanacaktır. Ardından da belirli süreli iş sözleşmelerinin yenilenmesinde aranan objektif neden koşulu incelenecektir. Bu çerçevede objektif neden koşuluna ilave olarak belirli süreli iş sözleşmelerinin yenilenmesinde kötüye kullanmaları engellemek için "süre sınırı" ve "sayı sınırı"nın hukukumuz açısından uygulaması değerlendirilecektir.

\section{Anahtar Kelimeler}

Belirli süreli iş sözleşmesi, Objektif neden, İş Kanunu m. 11, Türk Borçlar Kanunu, Deniz İş Kanunu, Basın İş Kanunu, Zincirleme süreli iş sözleşmesi, Yenilenme, Süre sınırı, Sayı sınırı

Determination of the Objective Reason Condition in the Conclusion and Renewal of Fixed Term Employment Contracts

\begin{abstract}
An employment contract may be executed for a fixed or indefinite term. An indefinite-term employment contract is the rule of thumb, whereas a fixed-term contract is an exception. According to Article 11 of the Employment Code No 4857, a fixed-term contract may be signed when it is based on an objective reason, such as fixed-term work, the completion of a certain job, or the emergence of a relevant fact. There is no similar provision in other employment codes, which is why concluding a fixed-term employment contract with a worker covered by the Employment Code is more difficult than terminating workers excluded from the said code. This strict structure to conclude a fixed-term employment contract of the Employment Code has been criticized by the doctrine. According to Article 11, paragraphs 2 and 3, of the Employment Code and Article 430 of the Obligation Code No. 6098, to renew a fixed-term employment contract with all workers, an objective reason is required. This article explains what "objective reason" means and if such a condition is suitable and evaluates the debates in the doctrine and legal studies regarding the objective reason condition in the conclusion of fixed-term employment contracts, regulated in Article 11 of the Employment Code. Further, the author discusses whether an exception should be introduced into the objective cause condition. This article next examines the objective
\end{abstract}

* Sorumlu Yazar: Canan Ünal Adınır (Dr. Öğr. Üyesi), Marmara Üniversitesi, Hukuk Fakültesi, İ̧̧ ve Sosyal Güvenlik Hukuku Anabilim Dalı, İstanbul, Türkiye. E-posta: canan.unal@marmara.edu.tr ORCID: 0000-0003-3783-5637

Atıf: U nal A dinir C, "Belirli Süreli İş Sözleşmesinin Yapılması ve Yenilenmesinde Objektif Ne den Ko şulunun Değerlendirilmesi" (2021) 79(3)

İstanbul Hukuk Mecmuası. Advanced online publication. https://doi.org/10.26650/mecmua.2021.79.3.2041 
reason condition for the renewal of fixed-term employment contracts. In this framework, in addition to the objective reason condition, the application of a "time limit" and a "number limit" will be evaluated to prevent abuse in the renewal of employment contracts by using successive fixed-term employment agreements.

\section{Keywords}

Fixed-term employment contract, Objective reason, Employment Code No. 4857, Obligation Code No. 6098, Maritime Employment Code, Press Employment Code, Successive employment contract, Renewal, Maximum total duration, Maximum number of renewals

\section{Extended Summary}

An employment contract may be executed for fixed or indefinite terms. An indefinite-term employment contract is the rule of thumb, whereas a fixed-term contract is an exception. This article, firstly, determines whether the objective reason condition is required to conclude and renew a fixed-term employment contract. Secondly, it explains "objective reason" and the consequences when there is no objective reason. This article concludes with a criticism of the provisions based on an objective reason to terminate and renew a fixed-term employment contract and some suggestions going forward.

The only code that requires the objective reason condition to conclude a fixedterm contract is Employment Code No. 4857 (hereafter "EC"). This code applies to all workers irrespective of their job, excluding the exceptions listed in Article 4. The EC provisions shall not be applied to such exceptions and workers who are covered by other special employment codes. Article 11 of EC is, therefore, applicable only to conclude (and renew) a fixed-term contract with workers covered by the EC.

Article 11 of the EC is as follows:

The written employment contract between the employer and the worker is called a fixed-term contract when it is based on an objective reason, such as fixed-term work, the completion of a certain job, or the emergence of a fact.

Accordingly, an employment contract that is not based on an objective reason will be considered an indefinite-term employment contract. Whether the lack of objective reason is considered automatically by the judge or can be put forward by the employer is a hot topic of debate. According to the majority and the latest judgments of the Court of Appeal, only the worker can put the lack of objective reason forward. This upholds Article 11's intent to protect workers by preventing the abuse of the employer's rights.

There are no similar provisions in other employment codes requiring an objective reason to conclude a fixed-term contract. For this reason, the EC is seen as the strictest code and is criticized by the doctrine. 
As a result of such debates, lawmakers introduced a modification to the law during the Turkish Grand National Assembly on November 5, 2020. A proposed modification of Article 11 included a provision that excepted workers in a certain age group from the condition of objective reason in the conclusion and renewal of a fixed-term employment contract. Such a provision is contrary to the prohibition of age discrimination; this is almost certainly why the provision have not been enacted.

In the author's opinion, exceptions regarding the objective reason condition can be foreseen by considering a balance between workers' protection and the need for flexibility of enterprises in the conclusion of a fixed-term employment contract. This being said, however, changes in the law should not bring about new legal problems.

Paragraphs 2 and 3 of Article 11 are as follows:

Unless there is a compelling reason, successive fixed-term employment contracts are not allowed. Otherwise, that employment contract is considered from the very beginning to be a contract for an indefinite term. A successive employment contract basing on a compelling reason maintains its status for a fixed term.

Here, the "compelling reason" is considered the same as the "objective reason" in paragraph 1 of Article 11. Accordingly, if there is a fixed-term contract and the objective reason subsists or a new objective reason arises, it is possible to renew the employment contract for a fixed term.

A similar provision appears in the Turkish Obligation Code No. 6098 (hereafter "OC"). Paragraph 2 of Article 430 of the OC is as follows: "If a fixed-term contract is continued implicitly after the end of its term, it turns into an indefinite-term contract. If there is a compelling reason, successive fixed-term employment contracts are allowed." This provision is applicable not only to employment relations under the $\mathrm{OC}$ but also to those under the Maritime Employment Code No. 854 (hereafter "Maritime EC") and the Press Employment Code No. 5953 (hereafter "Press EC"). This is because the EC is the general employment code and applies in the case of legal gaps that may exist in specific codes, including the Maritime EC and the Press EC.

While a fixed-term employment contract may be successively executed, there is no limit to the number of times and the length for which such a contract may be renewed. The doctrine and the judgments of the Court of Appeal suggest determining a limit on how many times and for how long an employment contract may be renewed. In the author's opinion, the best way forward is to add a paragraph to Article 11 of the EC and to Article 430 of the $\mathrm{OC}$ to set this limit. However, the legal instruments for the prohibition of abuse of the right and protection purpose of the articles prevent the contract from being renewed forever. Judges may make decisions by considering 
such instruments. For example, taking into consideration paragraph 3 of Article 430 of the OC, it should be accepted that fixed-term contracts with a total duration of more than 10 years. 


\title{
Belirli Süreli İş Sözleşmesinin Yapılması ve Yenilenmesinde Objektif Neden Koşulunun Değerlendirilmesi
}

\begin{abstract}
Giriş
Belirli süreli iş sözleşmeleri, iş hukukunun tarihsel gelişimi incelendiğinde, başlangıçta sözleşme serbestisi ilkesinin doğal bir sonucu olarak değerlendirilmiş ve herhangi bir sınırlamaya tabi olmaksızın kabul edilmiştir. 1960’l1 yıllardan itibaren ise, hukuk sistemlerinde işçinin korunması amacı ile, belirli süreli iş sözleşmelerinin sınırlandırılması eğilimi ortaya çıkmıştır. Ancak daha sonra küreselleşme ile birlikte artan rekabet koşullarına karşı koyabilmeleri için işletmelerin de gözetilmesi gerekliliği hasıl olmuştur. Bunun da sonucunda ülkemiz de dâhil gelişmiş hukuk sistemlerinde belirli süreli iş sözleşmesinin kurulması ve yenilenmesinde işçilerin korunması ile işletmelerin esneklik ihtiyacı arasında hassas bir denge oluşturulma çabası gözlenmektedir.
\end{abstract}

Hukukumuzda, belirli süreli iş sözleşmelerinin yapılması ve yenilenmesi için "objektif neden" koşuluna yer verilmekte olup bu koşul ile sözleşme serbestisi sınırlanmaktadır. Sinırlamanın nasıl öngörüldüğü ise, hassas dengenin sağlanması bakımından kritik bir öneme sahiptir.

$\mathrm{Bu}$ çalışma ile iş kanunlarında belirli süreli iş sözleşmesinin yapılmasında ve yenilenmesinde objektif neden koşulu açıklanacağı gibi bu koşulun esnekleşme ihtiyacı sonucu nasıl düzenlenmesi ve düzenlenmemesi gerektiği de incelenecektir. Çalışmanın yapılmasındaki temel motivasyon kaynağı, kamuoyunda "Torba Kanun Teklifi" olarak adlandırılan ve belirli süreli iş sözleşmesinin yapılmasında ve yenilenmesinde objektif neden koşulu bakımından istisnalar öngören İşsizlik Sigortası Kanunu ile Bazı Kanunlarda Değişiklik Yapılması Hakkında Kanun Teklifi' dirr'. İş yaşamında önemli tartışmalara sebep olan Torba Kanun Teklifi, yeni koronavirüs (Covid-19) pandemisinin yoğun şekilde tüm yaşamımıza tesir ettiği günlerde pandemi nedeniyle başta hizmetler sektörü olmak üzere işgücü arzında ve istihdamda yaşanan kayıpların giderilmesine katkı da sağlayacağı ifade edilerek ${ }^{2}$ TBMM gündemine taşınmıştı ${ }^{3}$. Torba Kanun Teklifi'nde, belirli süreli iş sözleşmesinin yapılması ve yenilenmesi için aranan objektifneden koşuluna "işçinin yirmibeş yaşını doldurmamış veya elli ve daha yukarı yaşta olması kaydıyla" istisna getirilmekte; yani bu kişiler ile objektif neden olmaksızın belirli süreli iş sözleşmesi yapılmasına ve sözleşmenin

Tam metne erişim için bkz < https://www2.tbmm.gov.tr/d27/2/2-3147.pdf > Erişim Tarihi 5 Kasım 2020.

Bkz Plan ve Bütçe Komisyonu raporu, 28 < https://www.tbmm.gov.tr/sirasayi/donem27/yil01/ss239.pdf > Erişim Tarihi 15 Aralık 2020.

16 Ekim 2020 tarihinde TBMM Başkanlığına iletilen 2/3147 esas nolu 5 Kasım 2020 tarihi itibariyle TBMM gündemine taşınmıştır. Bkz < https://www.tbmm.gov.tr/develop/owa/tasari_teklif_sd.onerge_bilgileri?kanunlar_sira_no=280687 > Erişim Tarihi 5 Kasım 2020. 
yenilenmesine imkan sağlanmaktayd $1^{4}$. Torba Kanun Teklifi'nde yer bulan bu düzenleme, kamuoyunda ciddi şekilde eleştirilmiş ${ }^{5}$ ve bu eleştiriler doğrultusunda kanunlaşma aşamasında yer almamıştır ${ }^{6}$. Ancak, belirli süreli iş sözleşmesinin yapılması ve yenilenmesinde kanuni değişiklik ihtiyacı hâlen mevcuttur. Dolayısıyla, bahsi geçen tartışmalı kanun teklifi isabetli olarak kanunlaşmasa da bu çalışmayı yapmak yönündeki akademik hevesimiz sona ermemiştir.

$\mathrm{Bu}$ heves ve arzu ile, çalışmamızda öncelikle belirli süreli iş sözleşmesinde “objektif neden” koşulu sözleşmenin ilk defa yapılması ve yenilenmesi bakımından iş kanunlarında yer verilen farklılıklara dikkat çekilerek anlatılacaktır. Ardından, “objektif neden” kavramı, örneklerle açıklanacaktır. Daha sonra, belirli süreli iş sözleşmesinin yapılması ve yenilenmesinde objektif nedenin bulunmamasının sonuçları irdelenecektir. En nihayetinde ise, mevcut düzenlemeye ilişkin görüş ve önerilerimize yer verilecektir. Bunu yaparken, Torba Kanun Teklifi ile öngörülen ancak kanunlaşmayan objektif nedene ilişkin istisna getiren düzenleme analiz edileceği gibi objektif neden koşulu dişında belirli süreli iş sözleşmesinin yenilenmesinde karşılaştırmalı hukukta rastlanan diğer koruma mekanizmaları olan süre ve sayı sinırlamaları da değerlendirilecektir.

\section{Belirli Süreli İş Sözleşmesinde Objektif Neden Koşulu}

\section{1. İş Kanunu Kapsamındaki İş İlişkilerinde}

\section{a. İş sözleşmesinin ilk defa yapılmasında}

4857 sayılı İş Kanunu m. 9 hükmü ile iş sözleşmesinin taraflarına kanuni sınırlamalar içinde kalmak kaydıyla iş sözleşmesi türünü ve çalışma biçimlerini belirleme serbestisi tanınmıştır. Ancak ardından 11. madde ile, İş Kanunu kapsamındaki ${ }^{7}$

\footnotetext{
Torba Kanun Teklifi'nde, 28. madde ile İș Kanunu'nun (Kanun Numarası: 4857, Kabul Tarihi: 22.05.2003, RG 10.06.2003/25134) 11. maddesine eklenmesi öngörülen fikra şu şekilde idi: "Belirli süreli işs sözleşmesi, işçinin yirmibeş yaşını doldurmamış veya elli ve daha yukarı yaşta olma koşulunu sağlaması kaydıyla birinci ve ikinci fikradaki koşullar aranmadan yazılı şekilde yapılabilir. Yirmibeş yaşını doldurmamış iş̧̧iler ile yapılacak belirli süreli işs sözleşmelerinin süresi iş̧̧inin yirmi beş yaşını doldurduğu tarihi geçmez. Bu fikra uyarınca bir defada veya yenilenerek yapılan belirli süreli iş sözleşmelerinin toplam süresi iki yll geçemez.".

5 Üç ișçi konfederasyonu (TÜRK-İȘ, HAK-İS ve DISK), Torba Kanun Teklifi'nin çalıșma hayatına ilișkin düzenlemelerine karșı yazılı olarak ortak açıklamada bulunmuştur. Ortak açıklamaya göre, "25 yaş altı ve 50 yaş üstü çalışanların hiçbir şarta bağgl olmaksızın belirli süreli iş sözleșmesi ile (geçici ișçi olarak) istihdam edilmesi sonucunda kıdem ve ihbar tazminatı gibi haklardan yararlanamamaları büyük haksızlıkların ortaya çıkmasına neden olacaktır. Yaşa bağlı olarak getirilecek bu düzenleme çalışanlar arasında ayrıma yol açacaktır. Çalıșma düzeni ve sosyal adaletin bozulmasına neden olacaktır. Ülkemizde belirsiz süreli iș sözleşmesi esasina dayalı olarak düzenlenen iş hukuku düzeninin alt üst olmasina yol açacaktır. Ayrıca yaşa bağlı olarak getirilen bu ayrım Anayasanın eșitlik ilkesine de aykırıdır.". Açılamanın tam metni için ș.< http://www.turkis.org.tr/TURK-IS--HAK-ISVE-DISKTEN-ORTAK-ACIKLAMA-d455751 > Erişim Tarihi 15 Aralık 2020; Torba Kanun Teklifi'ne ilişkin gazete haberi için bkzDeutsche Welle Türkiye, 'Torba Yasa Tartışması: Kıdem Tazminatı ve Emeklilik Hakkı Tehlikede' $(01.11 .2020)<$ https://www. dw.com/tr/torba-yasa-tartışması-kıdem-tazminatı-ve-emeklilik-hakkı-tehlikede/a-55455034 > Erişim Tarihi 15 Aralık 2020.

6 Bazı Alacakların Yeniden Yapılandırılması ile Bazı Kanunlarda Değişiklik Yapılması Hakkında Kanun, 7256, Kabul Tarihi: 11.11.2020, RG 17.11.2020/31307.

İş Kanunu kapsamındaki iş ilişkilerinde İş Kanunu m. 11 hükmünün özel hüküm olması sebebiyle, genel kanun olan TBK'nin 430.

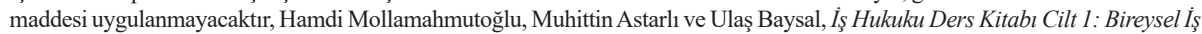
Hukuku, (4. Bas1, Lykeion 2020) 126; Yargitay 22 HD 34697/9344, 09.07.2020; Yargitay 9 HD 16506/6610, 29.06.2020.
} 
iş ilişkilerinde sözleşme türünü belirleme serbestisi, önemli sınırlamalara tabi k1lınmıştır". Söz konusu maddenin 1. fikrasında "İ̧̧ ilişkisinin bir süreye bağlı olarak yapılmadığı halde sözleşme belirsiz süreli sayılır. Belirli süreli işlerde veya belli bir işin tamamlanması veya belirli bir olgunun ortaya çıması gibi objektif koşullara bağlı olarak işveren ile iş̧̧i arasında yazılı şekilde yapılan iş sözleşmesi belirli süreli iş sözleşmesidir." şeklinde bir düzenlemeye yer verilmiştir.

$\mathrm{Bu}$ düzenleme ile hukukumuzda belirsiz süreli iş sözleşmesi esas olarak belirlenirken ancak objektif nedenlerden birinin varlığı hâlinde belirli süreli iş sözleşmesinin yapılmasına cevaz verilmiştir9 .

\section{b. Belirli süreli iş sözleşmesinin yenilenmesinde}

İş Kanunu m. 11 hükmünün 2. fikrasında, belirli süreli iş sözleşmesinin yenilenmesinde, başka ifadelerle üst üste yapılması veya zincirleme yapılmasında, sözleşmenin belirli süreli olma niteliğini koruyabilmesi için "esaslı neden" koşulunun mevcudiyeti aranmıştır. Söz konusu fikraya göre; "Belirli süreli iş sözleşmesi, esash bir neden olmadıkça, birden fazla üst üste (zincirleme) yapılamaz. Aksi hâlde iş sözleşmesi başlangıçtan itibaren belirsiz süreli kabul edilir.". Kanun metninde "esaslı neden" koşuluna yer verilmiş olmakla birlikte bu koşulun aynı maddenin 1. fikrasında belirli süreli iş sözleşmesinin hukuka uygun olarak bağıtlanabilmesi için aranan "objektif nedenler" ile özdeş kabul edilmektedir"10.

Bu sınırlama, sözleşme özgürlüğünün özüne dokunmadığı ve özgürlüğün kullanılmasını olanaksız kılmadığı için Anayasaya aykırılık oluşturmaz, Öner Eyrenci, Savaş Taşkent ve Devrim Ulucan, Bireysel Iş̧ Hukuku (10. Bası, Beta 2020), 71.

$9 \quad$ Nuri Çelik, Nurşen Caniklioğlu ve Talat Canbolat, Işs Hukuku Dersleri (33. Bası, Beta 2020) 192-193; Süzek (n 9) 239; Eyrenci, Taşkent ve Ulucan (n 8) 71; Talat Canbolat, 'Mevzuatta Öngörülen Bazı İş Sözleşmesi Türlerinin 4857 sayılı İş Kanununun Belirli Süreli İş Sözleşmesine İlişkin Esasları Yönünden Değerlendirilmesi'(2007) 4 (13) Legal İHSGHD 187, 194; Ali Güzel, Ercüment Özkaraca ve Deniz Ugan, 'Karşılaştırmalı Hukukta ve Türk Hukukunda Belirli Süreli İş Sözleşmesi: Yapılma ve Yenilenme Koşulları' iç Süleyman Başterzi (ed) Prof. Dr. Sarper Süzek'e Armağan C. 1 (Beta 2011) 475, 561; Yeliz Bozkurt Gümrükçüoğlu, Türk İş Hukuku'nda Belirli Süreli İş Sözleşmesi (1. Bası, Vedat 2012) 159; doktrinde azınlık görüşü tarafindan İş Kanunu m. 11 hükmünde yer alan "objektif koşul" ile kastedilenin maddenin dayanağı olan Avrupa Birliği Direktifi ile aranan “objektif neden”den farklılaştığı; dolayısıyla belirli süreli iş sözleşmesinin ilk kez yapılmasında objektif neden aranmasına gerek olmadığı savunulmaktadır. Azınlık görüşü için bkz Savaş Taşkent, 'Belirli Süreli İş Sözleşmelerinde "Esaslı Neden’ Sorunu”" (2011) 24 Sicil Dergisi 19, 28; Başak Güneş ve Faruk Barış Mutlay, 'Yeni Borçlar Kanununun 'Genel Hizmet Sözleşmesi’ne İlişkin Hükümlerinin İş Kanunu ve 818 Sayılı Kanunla Karşıllaştırılarak Değerlendirilmesi' (2011) 30 (3) Çalışma ve Toplum Dergisi 231, 241.

10 Çelik, Caniklioğlu ve Canbolat (n 9) 200; Süzek (n 9) 249; Mollamahmutoğlu, Astarlı ve Baysal (n 7) 130; Ünal Narmanlığlu, 'Belirli Süreli İş Sözleşmesini Sona Erdiren Olgular ve İşlemler' (2012) 9 (35) Legal İHSGHD 3, 11; Gülsevil Alpagut, ‘ 4857 Sayılı Yasa Çerçevesinde Belirli Süreli Hizmet Sözleşmesi’ (2004) 43 Mercek Dergisi 73, 85; Canbolat (n 9) 194; Mikdat Güler, 'Belirli Süreli İş Sözleşmesi’ (2005) 2 (5) Legal İHSGHD 27, 41-42; Süleyman Başterzi, ‘Avrupa Birliği Konseyinin 99/70 Sayılı Yönergesi Işığında Belirli Süreli İş Sözleşmesi Yapma Koşulları ve 4857 Sayılı İş Kanununun Öngördüğü Sistem' (2006) İş Hukuku ve Sosyal Güvenlik Hukuku Türk Milli Komitesi 30. Y1l Armağanı, 119, 133; Süleyman Başterzi, 'Belirli Süreli İşs Sözleşmesinin Yapılmasına İlişkin Objektif Nedenlerin Tespitinde Menfaatler Dengesi İşçinin Haklı Menfaati' (2013) 15 (Özel Sayı) DEÜHFD 423, 424; Güzel, Özkaraca ve Ugan (n 9) 558; Bozkurt Gümrükçüoğlu, Belirli Süreli İş Sözleşmesi (n 9) 160, 161, 267; H Hadi Sümer, İş Hukuku Uygulamaları (7. Bası, Seçkin 2019) 174; H Hadi Sümer, 'Özel Öğretim Kurumu Öğretmenlerinin İş Sözleşmelerinin Hukuki Niteliği' (2016) 15 (11) İstanbul Kültür Üniversitesi Hukuk Fakültesi Dergisi 407, 433; Fatih Uşan ve Canan Erdoğan, İs ve Sosyal Güvenlik Hukuku (1. Bas1, Seçkin 2020), 86; Tankut Centel, Introduction to Turkish Labaur Law (1 st edn, Springer 2017) 72; Güven ve Aydın (n 10) 106; Yusuf Yiğit, 'Belirli Süreli İş Sözleşmesi Yapma Serbestisi ve Bu Serbestinin Sınırları' (2012) 14 (2) DEÜHFD 101, 129; benzer yönde, Eyrenci, Taşkent ve Ulucan (n 8) 74; aksi yönde, Taşkent (n 9) 25. Nitekim madde gerekçesinde de "esaslı neden", "objektif neden" ile aynı anlamda olarak ifade edilmiştir; "... belirli süreli hizmet akitlerinin esaslı (objektif) bir neden olmadıkça üst üste yapılmalarının önlenmesi de gerekmektedir." 


\section{Türk Borçlar Kanunu Kapsamındaki İş İlişsilerinde}

6098 say1lı Türk Borçlar Kanunu'nun ${ }^{11}$ (TBK) 393. maddesinde, iş sözleşmesi tanımlanırken işçinin belirli veya belirli olmayan süreyle iş görmeyi üstlendiği sözleşme olduğuna değinilmiş; ancak belirli süreli iş sözleşmesi yapılması için objektif neden koşulu öngörülmemiştir.

Ayrıca belirli süreli iş sözleşmesinin sona ermesini düzenleyen TBK m. 430 hükmünde de belirli süreli sözleşmenin, süresinin bitiminden sonra örtülü olarak sürdürülmesi halinde, belirsiz süreli sözleşmeye dönüştügüne; ancak, esaslı bir sebebin varlı̆̆ hâlinde, üst üste belirli süreli hizmet sözleşmesi kurulabileceğine yer verilmiştir. $\mathrm{Bu}$ düzenlemeden de belirli süreli iş sözleşmesinin kurulmasına ilişkin objektif neden arandığı anlamı çıkmamaktadır. Aksine her iki madde birlikte değerlendirildiğinde belirli süreli iş sözleşmesinin yenilenmesinde objektif nedeni arayan kanun koyucunun sözleşmesinin ilk defa yapılmasında sustuğu görülecektir ${ }^{12}$.

Nitekim, TBK m. 430 hükmünün gerekçesinde de düzenleme bakımından İş Kanunu'nun 11. maddesinin 2. ve 3. fikrasından yararlanıldığı ifade edilmiştiri ${ }^{13}$. $\mathrm{Bu}$ fikralar, belirli süreli iş sözleşmesinin yenilenmesine ilişkin olup belirli süreli iş sözleşmesinin ilk defa yapılmasına ilişkin sınırlamaları içeren 1. fikra, gerekçede de belirtilmemiştir. Dolayısıyla, TBK'ye tabi iş ilişkileri bakımından sözleşme taraflarının sözleşme türünü belirleme serbestisi olduğu sonucuna ulaşılmaktadır ${ }^{14}$.

Belirli süreli iş sözleşmesinin yenilenmesinde ise, sözleşmenin ilk defa yapılmasından farklı olarak, kanunun açık hükmü gereği objektifneden aranmaktadır ${ }^{15}$. Madde gerekçesinde de belirtildiği üzere; "Aynı fikranın son cümlesinde ise, 4857 sayll İ̧S Kanununun 11 inci maddesinin ikinci ve son fikralarından yararlanılmıştır. Böylece, esaslı bir sebep olmadıkça, aynı iş̧̧i ile belirli süreli hizmet sözleşmesinin üst üste yapılması durumunda bu sözleşmeler belirsiz süreli sözleşmeye dönüşecek, işçi bu tür sözleşmelerin koşullarından ve bu arada feshe karşı korunmaya ilişkin yasal hükümlerden yararlanacaktır. Buna karşılık, belirli süreli sözleşmelerin zincirleme

11 Kabul Tarihi: 11.01.2011, RG 04.02.2011/27836.

12 TBK m. 430 hükmü, İș Kanunu kapsamındaki iș sözleşmeleri bakımından uygulama bulmayacaktır. Zira, İş Kanunu m. 11 hükmü, özel hükümdür. Bkz Polat Soyer, 'Hizmet Sözleşmesinin Sona Ermesine İlişkin 'Yeni' Türk Borçlar Kanunu Hükümleri ve İş Hukuku Bakımından Önemi' (2011) 22 Sicil Dergisi 12, 13; Narmanlıoğlu (n 10) 11; Nurşen Caniklioğlu, 'Türk Borçlar Kanununun Hizmet Sözleşmesinin Kurulmasına, Tarafların Hak ve Borçlarına İlişkin Hükümlerinin Genel Bir Değerlendirilmesi' (2012) Çalışma Hayatı Açısından Yeni Borçlar Kanunu ve Ticaret Kanunu Semineri, 20-21 Eylül 2011, Türkiye İşveren Sendikaları Konfederasyonu, 78, 85; Gülsevil Alpagut, 'Türk Borçlar Kanununun Hizmet Sözleşmesinin Devri, Sona Ermesi, Rekabet Yasağı, Cezai Șart ve İbranameye İlișkin Hükümleri’ (2011) 8 (31) Legal İHSGHD 913, 929930; Kübra Doğan Yenisey, 'Hizmet Sözleşmesi' iç Murat İnceoğlu (ed) Türk Borçlar Kanunu Sempozyumu (On İki Levha 2012) 297, 326; Başterzi, ‘Objektif Neden' (n 10) 433.

13 Polat Soyer, ‘6098 Sayılı Türk Borçlar Kanunu’nda Yer Alan ‘Genel Hizmet Sözleşmesi’ne İlişkin ‘Bazı’ Hükümlerin İş Hukuku Açıssından Önemi’ (2012) İş Hukukunda Güncel Sorunlar 2, 25 Mayıs 2012, $1,11$.

14 Soyer, ‘6098 Sayılı Türk Borçlar Kanunu' (n 13) 11; Doğan Yenisey, 'Hizmet Sözleşmesi' (n 12) 301; aynı yönde, Taşkent (n 9) 20; Güneş ve Mutlay, (n 9) 240; Mollamahmutoğlu, Astarlı ve Baysal (n 7) 126.

15 Kanunda yer verilen "esaslı sebep" ifadesinin İş Kanunu'na paralel olarak değerlendirilmesi gerektiği yönünde, Caniklioğlu, 'Türk Borçlar Kanunu' (n 12) 84; Alpagut, 'Türk Borçlar Kanunu’ (n 12) 929. 
yapılmasında esaslı bir sebep varsa, belirli süreli sözleşme olma özellikleri varlı̆̆ını sürdürecektir.".

\section{Basın İş Kanunu Kapsamındaki İş İlişsilerinde}

5953 sayılı Basın İş Kanunu’nda ${ }^{16}$ (BİK) belirli süreli iş sözleşmesinin yapılması ve yenilenmesinde herhangi bir sınırlandırmaya yer verilmemiştir. TBK'nin BİK bakımından genel kanun olması sebebiyle özel kanunda yer alan bu konudaki boşluğun TBK m. 430 hükmü uygulanarak doldurulması gerekecektir. TBK m. 430 hükmü dikkate alındığında ise, BİK kapsamında yer alan, gazetecilerle belirli süreli iş sözleşmesinin ilk defa yapılmasında objektif neden aranmadığı sonucuna ulaşılırken ${ }^{17}$; sözleşmenin yenilenmesi objektif nedenin varlığına bağlı olacaktır ${ }^{18}$.

\section{Deniz İş Kanunu Kapsamındaki İş İlişkilerinde}

854 sayılı Deniz İş Kanunu'nda ${ }^{19}$ (DİK) belirli süreli iş sözleşmesinin ilk defa yapılmasında herhangi bir sınırlandırmaya yer verilmemiştir. Hatta kanunun 7. maddesinde, iş sözleşmesinin belirli süre veya sefer için yahut süresiz olarak yapılabileceği belirtilmiştir. Dolayısıyla; DİK kapsamında yer alan gemiadamları ile ilk defa belirli süreli iş sözleşmesi yapılmasında objektif neden aranmamaktadır ${ }^{20}$. Yargıtay'ın da kararları bu yöndedir ${ }^{21}$.

Deniz İş Kanunu’nda, belirli bir süre için yapılmış olan iş sözleşmesinin sonunda gemiadamı, işveren veya işveren vekilinin muvafakatiyle işe devam ederse iş sözleşmesinin aynı süre için uzatılmış sayılacağı belirtilmiştir (m. 8). DİK kapsamında belirli süreli iş sözleşmesinin yenilenmesi bakımından doktrinde TBK m. 430 hükmünün uygulanıp uygulanmayacağına ilişkin farklı görüşler mevcuttur. Bazı yazarlar, DİK m. 8 hükmünün özel bir düzenleme olması sebebiyle TBK m. 430 hükmünün uygulanmayacağını savunurken ${ }^{22}$ bazı yazarlar ise uygulanacağını ileri sürmektedirler ${ }^{23}$. Yargıtay 9. Hukuk Dairesi’nin yerleşmiş içtihatlarında ise TBK m.

\footnotetext{
16 Basın Mesleğinde Çalışanlarla Çalıştıranlar Arasındaki Münasebetlerin Tanzimi Hakkında Kanun, Kabul Tarihi: 03.06.1952, RG 20.06.1952/8140

17 Caniklioğlu, 'Türk Borçlar Kanunu' (n 12) 84; Alpagut, 'Türk Borçlar Kanunu’ (n 12) 930; Ercan Akyiğit, Bireysel İs Hukuku Dersleri (1. Bası, Seçkin 2020) 120; krş Doğan Yenisey, 'Hizmet Sözleşmesi’ (n 12) 326.

18 Caniklioğlu, 'Türk Borçlar Kanunu' (n 12) 84; Alpagut, 'Türk Borçlar Kanunu' (n 12) 930; Doğan Yenisey, 'Hizmet Sözleşmesi' (n 12) 326; Akyiğit (n 17) 120; aynı yönde, Soyer, 'Hizmet Sözleşmesi' (n 12) 13; Narmanlığlu, (n 10$) 11$.

19 Kabul Tarihi: 20.04.1967, RG 29.04.1967/12586.

20 Caniklioğlu, 'Türk Borçlar Kanunu' (n 12) 84; Alpagut, 'Türk Borçlar Kanunu’ (n 12) 930; krş Doğan Yenisey, 'Hizmet Sözleşmesi' (n 12) 326.

21 Yargitay 9 HD, 9036/8163, 09.05.2017; Yargitay 9 HD, 22725/5978, 14.03.2016; Yargitay 9 HD, 10445/6930, 17.02.2015; Yargitay 9 HD, 1962/36536, 02.12.2014; Yargitay 9 HD, 1963/36537, 02.12.2014; Yargitay 22 HD, 28100/29667, 30.10.2014; Yargitay 9 HD, 7792/12652, 29.04.2013; Yargitay 9 HD, 3655/12648, 29.04.2013; ayrica İstanbul BAM 28 HD, 3191/164, 13.02.2020; İzmir BAM 15 HD, 1891/638, 30.04.2018.

22 Soyer, 'Hizmet Sözleşmesi' (n 12) 13; Narmanlıŏlu, (n 10) 11; Doğan Yenisey, 'Hizmet Sözleşmesi' (n 12) 326.

23 Caniklioğlu, ‘Türk Borçlar Kanunu' (n 12) 84; Alpagut, 'Türk Borçlar Kanunu' (n 12) 930; DíK’de boşluk olduğunun kabulü hâlinde TBK m. 430/2 hükmü gereği sözleşmenin yenilenmesinde objektif neden aranacağı yönünde, Akyiğit (n 17) 120.
} 
430 hükmü dikkate alınmakta ve Deniz İş Kanunu kapsamındaki iş sözleşmelerinin yenilenmesinde "objektif ve esaslı bir neden" aranmaktadır²4. Nitekim 2019 yılında verdiği kararlarda Özel Daire açıkça "Borçlar Kanunu genel kanun olduğundan, gemi adamı ile belirli süre için yapılan iş sözleşmelerinin yenilenmesinde esaslı nedenin varlığı aranmalıdır." ifadelerine yer vermiştir ${ }^{25}$.

\section{5. İş Kanunlarında Öngörülen Esasların Mukayesesi}

Belirli süreli iş sözleşmesinin ilk defa yapılmasında ve yenilenmesinde, farklı kanunlarda farklı esaslar öngörülmüş olup bu esaslar yukarıda detaylı olarak açıklanmıştır. Kanunlara ilişkin mukayeseli bir değerlendirme yapıldığında; belirli süreli iş sözleşmesi yapılması için aranan koşulların en katı olduğu kanunun İş Kanunu olduğu sonucuna ulaşılmaktadır. Zira; belirli süreli iş sözleşmesinin yapılmasında objektif neden koşuluna sadece İş Kanunu m. 11 hükmünde yer verilmiştir. Ne BİK ile TBK kapsamındaki işçiler bakımından uygulama bulan TBK m. 430 hükmünde ne de Deniz İş Kanunu'nda belirli süreli iş sözleşmesinin ilk defa yapılmasında objektif neden koşulu aranmaktadır.

Belirli süreli iş sözleşmesinin yenilenmesi bakımından ise, İş Kanunu m. 11 hükmüne benzer esaslar öngören TBK m. 430 hükmü, objektif neden koşuluna yer vermektedir. DİK kapsamındaki işçiler ile belirli süreli iş sözleşmesinin yenilenmesi bakımından ise doktrinde aksi görüşlere rağmen Yargıtay TBK m. 430 hükmünü dikkate alarak objektif neden koşulu aramaktadır. Dolayısıyla, DİK kapsamındaki işçiler ile BİK ve TBK kapsamındaki işçiler belirli süreli iş sözleşmesinin yenilenmesinde İş Kanunu kapsamındaki işçiler gibi objektif neden koşuluna tabidir.

\section{Objektif Neden Kavramı}

\section{Genel Olarak}

Objektif neden, Türk iş hukuku doktrininde belirsiz süreli iş sözleşmesinin kural, belirli süreli iş sözleşmesinin ise istisna olduğu yönündeki ilkeden ayrılmayı haklı k1labilecek durumlar olarak tanımlanmıştır ${ }^{26}$.

İş kanunlarında ise objektif nedene ilişkin bir tanım bulunmamaktadır. Yine İş Kanunu m. 11 hükmünün kaynağı olan Uluslararası Çalışma Örgütü'nün (ILO) 158

\footnotetext{
Yargitay 9 HD, 3339/13024, 11.06.2019; Yargitay 9 HD, 22725/5978, 14.03.2016; ayrıca bkz Yargitay 9 HD, 1962/36536, 02.12.2014; Yargitay 9 HD, 1963/36537, 02.12.2014; Yargitay 9 HD, 7792/12652, 29.04.2013; Yargitay 9 HD, 3655/12648, 29.04.2013; ayrica bkz İstanbul BAM 28 HD, 3191/164, 13.02.2020.

25 Yargitay 9 HD, 3339/13024, 11.06.2019; Yargitay 9 HD, 906/10082, 07.05.2019.

26 Başterzi, 'Objektif Neden' (n 10) 427.
} 
sayılı Sözleşmesi27 ile Avrupa Konseyi’nin 1999/70 sayılı Direktifi ile yürürlüğe konulan Belirli Süreli İş Sözleşmeleri Hakkında Çerçeve Antlaşma'da ${ }^{28}$ da objektif neden kavramına ilişkin bir tanımlama yapılmamıştır. Ancak Avrupa Birliği hukukunun Avrupa Birliği ülkelerinde aynı şekilde yorumlanması ve uygulanmasını sağlamakla görevli yargı organı olan Avrupa Birliği Adalet Divanı (ABAD) tarafından Adeneler kararı ile objektif neden kavramına ilişkin önemli açıklamalar yapılmıştır. Söz konusu karara göre, “...objektif neden kavramı, Çerçeve Antlaşma'nın 5/1 (1) maddesi anlamında belirli bir faaliyeti niteleyen ve bu bağlamda zincirleme belirli süreli iş sözleşmelerine başvurulmasını haklı kılabilecek kesin ve somut koşullar biçiminde anlaşılmalıdır. Bu koşullar, bu sözleşmelerle ifa edilmesi amaçlanan işlerin özel niteliğinden ve bu işlerin doğasında var olan özelliklerinden veya gerektiğinde üye bir devletin elde etmeyi amaçladı̆̆ meşru bir sosyal politika hedefinden kaynaklanabilir." 29 .

İş Kanunu'nda objektif neden kavramı tanımlanmasa da 11. madde ile belirli süreli iş sözleşmesi tanımlanırken sözleşmeyi sürelendirme imkânı veren objektif nedenleri belirlemeye yarayan genel ölçütler soyut bir yaklaşımla sayılmıştır ${ }^{30}$. İş Kanunu m. 11 hükmüne göre, "Belirli süreli işlerde veya belli bir işin tamamlanması veya belirli bir olgunun ortaya çıkması gibi objektif koşullara bağlı olarak işveren ile işçi arasında yazılı şekilde yapılan iş sözleşmesi belirli süreli iş sözleşmesidir.”. Görüldüğü üzere, iş sözleşmesini sürelendirme imkânı veren, yani belirli süreli iş sözleşmesi yapılmasına imkân veren objektif nedenler; "belirli süreli işler”, "belli bir işin tamamlanması" ve "belirli bir olgunun ortaya çıkması” şeklinde örnekseme usulüyle sayılmıştır. Madde hükmünde "gibi” ifadesine yer verilerek sayılan durumlar dışında da objektif nedenlerin varlığına işaret edilmiştir ${ }^{31}$.

Soyut bir yaklaşımla ve örnekseme usulüyle sayılan objektif nedenlerin içi doktrin ve yargı tarafından doldurulmaktadır ${ }^{32}$. Doktrin tarafından bir iş sözleşmesinin sürelendirilmesine imkân verecek objektif nedenin tespitinde, tarafların meşru

Uluslarası Çalışma Örgütü’nün İş Sözleşmesinin Feshine İlişkin 158 sayılı Sözleşmesi için bkz https://www.ilo.org/dyn/ normlex/en/f?p=NORMLEXPUB:12100:0::NO::P12100_ILO_CODE:C158 (Erişim tarihi: 22.01.2021).

28 Avrupa Konseyi'nin 1999/70 sayılı Direktifi ve eki Belirli Süreli İş Sözleşmeleri Hakkında Çerçeve Antlaşma için bkz https://eur-lex.europa.eu/legal-content/EN/TXT/HTML/?uri=CELEX:31999L0070\&from=EN (Erişim tarihi: 05.11.2020).

29 C-212/04 Konstantinos Adeneler ve Diğerleri- Ellinikos Organismos Galaktos (ELOG) [2006], ABAD I-06057, para. 69-70; karara ilişkin ayrıca bkz Ali Güzel ve Emre Ertan, 'Avrupa Birliği Hukukunda ve Özellikle Avrupa Toplulukları Adalet Divanı (ATAD) Kararlarında Belirli Süreli İş Sözleşmesinin Yapılması ve Yenilenme Koşulları’ (2008) 5 (18) Legal İHSGHD 395, 409; Bozkurt Gümrükçüoğlu, Belirli Süreli İ̧̧ Sözleşmesi (n 9) 161-162.

30 Başterzi, 'Objektif Neden' (n 10) 424; Süleyman Başterzi, 'İş İlişkisinin Kurulması, Hükümleri ve İşin Düzenlenmesi Açısından Yargıtayın 2009 Yılı Kararlarının Değerlendirilmesi’ (2011) Yargıtayın İș Hukuku ve Sosyal Güvenlik Hukuku Kararlarının Değerlendirilmesi 2009, 1, 61-62; Bozkurt Gümrükçüoğlu, Belirli Süreli İş Sözleşmesi (n 9) 159.

31 Kanun hükmünde sayılan objektif nedenlerin tahdidi olmadığı yönünde, Yargıtay 22 HD, 15766/17747, 14.06.2016; ayrıca YİBGK, 10/1, 08.03.2019.

32 Başterzi, ‘Objektif Neden’ (n 10) 425; Başterzi, ‘Avrupa Birliği Konseyi’ (n 10) 133. 
menfaatleri arasındaki sosyal dengenin gözetilmesi gerektiği ifade edilmektedir ${ }^{33}$. Objektif nedenin mevcudiyeti için, geçicilik unsuru bulunmalıdır; yani, somut olayın özellikleri dikkate alındığında geçici bir süre için işçi ihtiyacının objektif olarak ortaya çıkması hâlinde sürelendirme imkânı veren objektif nedenin varlığından bahsedilebilecektir ${ }^{34}$. Aşağıda, İş Kanunu m. 11 hükmünde sayılan objektif nedenler doktrin ve yargı kararlarından örneklerle açıklanacaktır. Ayrıca kanunda sayılmamasına rağmen objektif neden olarak kabul edilen benzer durumlar da izah edileceği gibi başka kanunlardan kaynaklanan belirli süreli iş sözleşmeleri de kısaca anlatılacaktır.

\section{2. İşin Belirli Süreli Olması}

İş Kanunu m. 11 hükmü uyarınca belirli süreli iş sözleşmesi yapılmasına imkân veren objektif nedenlerden ilki, "işin belirli süreli olması”dır. Bu ifade ile kastedilen, işin niteliği itibariyle sözleşme yapıldığı sırada sözleşme konusu işin ne kadar süreceğinin taraflarca öngörülebilir olmasıdır ${ }^{35}$.

Bir serginin veya konferansin ya da bir sportif organizasyonun düzenlenmesinde işin ne kadar süreceği bilindiğinden, bu işlerde çalıştırılmak üzere işçi alınması hâli belirli süreli iş sözleşmesinin işin belirli süreli olması sebebiyle yapıldığı hâllerdendir ${ }^{36}$. Aynı şekilde, bir mevsim veya kampanya dönemi için yapılan iş sözleşmeleri ${ }^{37}$ de, sürenin sonu öngörülebildiğinden belirli süreli olarak kurulabilir. Örneğin yaz (turistik) mevsiminde açık olan veya bütün yıl açık olmakla beraber bu dönemde iş yoğunluğu artışı olan bir otelde salt yaz mevsimi için işe alınan işçilerle

33 Gülsevil Alpagut, Belirli Süreli Hizmet Sözleşmesi (1. Bası, Mavi 1998) 74-75; Başterzi, ‘Avrupa Birliği Konseyi’ (n 10) 135; Bașterzi, ‘Objektif Neden' (n 10) 426; Bozkurt Gümrükçüoğlu, Belirli Süreli İș Sözleşmesi (n 9) 160; Asiye Șahin Emir, 'Belirli Süreli İş Sözleşmesine İlişkin Sınırlamalar ve Esneklik Olanakları Avrupa Birliği Örnekleriyle' (2016) 18 (1) DEÜHFD 113, 124

34 Geçicilik unsuru için bkz Ömer Ekmekçi ve Esra Yiğit, Bireysel İş Hukuku Dersleri (1. Bası, On İki Levha 2020) 37; Bozkurt Gümrükçüoğlu, Belirli Süreli İ̧s Sözleşmesi (n 9) 160; ayrıca bkz Güzel, Özkaraca ve Ugan (n 9) 561.

35 Süzek (n 9) 241; Eyrenci, Taşkent ve Ulucan (n 8) 72; Devrim Ulucan, '4857 Sayılı Kanuna Göre İș Sözleşmesi Türleri' (2003) Yeni İş Yasası, 25-29 Haziran 2003, Toprak, Seramik, Çimento ve Cam Sanayi İşyerleri Sendikası Yayını, 35, 42; Alpagut, '4857 Sayılı Yasa' (n 10) 78; Canbolat (n 9) 195; Güler (n 10) 42; Güzel, Özkaraca ve Ugan (n 9) 536; Bozkurt Gümrükçüoğlu, Belirli Süreli İş Sözleşmesi (n 9) 184; Sümer, İş Hukuku Uygulamaları (n 10) 46; Sümer, 'Özel Öğretim Kurumu Öğretmenleri' (n 10) 425; Centel, (n 10) 72; Yiğit (n 10) 134; Şahin Emir (n 33) 125-126; YİBGK, 10/1, 08.03.2019; kanun hükmünde "belirli süreli işlerde" ifadesi yerine "niteliği gereği belirli süreli işlerde" ifadesine yer verilmesi yönündeki öneri için bkz Süzek (n 9) 240-241.

36 YIBBGK, 10/1, 08.03.2019; Süzek (n 9) 241; Canbolat (n 9) 187, 195; fuar organizasyonunda üretilen ürünlerin tanıtımı işinin süresi de bilinebilir olduğundan belirli süreli iş sözleşmesi yapılabileceği yönünde, Mollamahmutoğlu, Astarlı ve Baysal (n 7) 129.

37 Doktrinde mevsimlik ve kampanya ișlerini diğer objektif neden olan "bir olgunun ortaya çıkması" koșulu altında da incelemiş; mevsim ve kampanya döneminde iş gücü ihtiyacının artması olgusuna bağlı olarak belirli süreli iş sözleşmesi yapılabileceği savunulmuştur. Bkz Çelik, Caniklioğlu ve Canbolat (n 9) 194-195; Yiğit (n 10) 140; ayrıca bkz Aydın Başbuğ ve Mehtap Yücel Bodur, İş Hukuku (5. Bası, Beta 2018) 121. Mevsimlik ve kampanya işlerini diğer objektif neden olan "belirli bir işin tamamlanması" koşulu altında da inceleyenler olmuştur. Bkz Akyiğit (n 17) 117; Güven ve Aydın (n 10) 103 Mevsim ve kampanya işlerinde iş sözleşmesinin süreli olarak yapılabilmesi için objektif neden hakkında detaylı bilgi için bkz Alpagut, Belirli Süreli (n 33) 105-108. 
belirli süreli sözleşme yapılabilir ${ }^{38}$. Nitekim Yargıtay da tek bir mevsim için belirli süreli iş sözleşmesi yapılabileceğini belirtmektedir ${ }^{39}$.

\section{Belirli Bir İșin Tamamlanması}

İş Kanunu m. 11 hükmü uyarınca belirli süreli iş sözleşmesi yapılmasına imkân veren ikinci objektif neden, "belirli bir işin tamamlanması"dır. Bununla kastedilen, işçi ile zaman içinde devam edip giden bir iş için değil de tamamlanması ile sona erecek bir işte çalıştırılmak üzere belirli süreli iş sözleşmesi kurulmasıdır ${ }^{40}$. Belirli bir işin tamamlanması ile kastedilen yarım kalan bir işin tamamlanması olabileceği gibi, henüz başlanmamış bir işin tamamlanması da olabilir ${ }^{41}$.

Bina yapımının bitirilmesi ${ }^{42}$, viyadük-otoyol inşaatının bitirilmesi ${ }^{43}$, bilgisayar donanımının kurulması ${ }^{44}$, makinenin montaj145, sıva ve mozaik işlerinin tamamlanmasi ${ }^{46}$, projenin bitirilmesi ${ }^{47}$, bahçe düzenlenmesinin gerçekleştirilmesi ${ }^{48}$, fuar ya da festivalin bitirilmesi ${ }^{49}$ için belirli süreli sözleşme yapılması belirli bir işin tamamlanması objektif nedenine dayalı sürelendirme örnekleridir.

38 YİBGK, 10/1, 08.03.2019; Süzek (n 9) 241; Canbolat (n 9) 195-196; ayrıca bkz Güler (n 10) 43; Güven ve Aydın (n 10) 103.

39 “Mevsimlik işs sözleşmeleri 4857 Sayll İş Kanunu'nun 11. maddesindeki hükümlere uygun olarak, belirli süreli olarak yapılabileceği gibi belirsiz süreli olarak da kurulabilir. Tek bir mevsim için yapılmış belirli süreli iş sözleşmesi, mevsimin bitimi ile kendiliğinden sona erer ve bu durumda iş̧̧i ihbar ve kıdem tazminatına hak kazanamaz. Buna karşıllk, işçi ile işveren arasında mevsimlik bir işte belirli süreli iş sözleșmesi yapılmış ve izlenen yıllarda da zincirleme mevsimlik iş sözleşmeleriyle çalışılmışsa, değinilen maddenin son fikrası uyarınca iş sözleşmesi belirsiz süreli nitelik kazanacaktır." Yargitay 9 HD, 1298/5240, 10.06.2020; Yargitay 22 HD, 25992/22676, 09.12.2019.

40 YİBGK, 10/1, 08.03.2019; Yargitay 7 HD, 16480/23889, 01.12.2015.

${ }_{41}$ YİBGK, 10/1, 08.03.2019; Eyrenci, Taşkent ve Ulucan (n 8) 72; Ulucan, ‘4857 Sayılı Kanun' (n 35) 42; Sümer, İ̧ Hukuku Uygulamaları (n 10) 46; Bozkurt Gümrükçüoğlu, Belirli Süreli İ̧s Sözleşmesi (n 9) 213; Güler (n 10) 42; Şahin Emir (n 33) 127.

42 YİBGK, 10/1, 08.03.2019; Süzek (n 9) 241; Çelik, Caniklioğlu ve Canbolat (n 9) 193; Güzel, Özkaraca ve Ugan (n 9) 539; Mollamahmutoğlu, Astarlı ve Baysal (n 7) 129; Eyrenci, Taşkent ve Ulucan (n 8) 72; Bozkurt Gümrükçüoğlu, Belirli Süreli İş Sözleşmesi (n 9) 213; E Tuncay Senyen Kaplan, 'Belirli Süreli İş Sözleşmesinin Haksız Feshinin Hüküm ve Sonuçları' (2016) 36 Sicil Dergisi 17, 19; Centel (n 10) 72; Güven ve Aydın (n 10) 103; Yiğit (n 10) 121.

43 Akyiğit (n 17) 117; ayrıca Güven ve Aydın (n 10) 103.

44 YİBGK, 10/1, 08.03.2019; Süzek (n 9) 241; Canbolat (n 9) 195-196.

45 Çelik, Caniklioğlu ve Canbolat (n 9) 193; Mollamahmutoğlu, Astarlı ve Baysal (n 7) 129; Canbolat (n 9) 195.

46 Çelik, Caniklioğlu ve Canbolat (n 9) 193.

47 YİBGK, 10/1, 08.03.2019; Süzek (n 9) 241; Çelik, Caniklioğlu ve Canbolat (n 9) 193-194 Canbolat (n 9) 195; Başterzi, ‘Avrupa Birliği Konseyi’ (n 10) 134; Güzel, Özkaraca ve Ugan (n 9) 539; Mollamahmutoğlu, Astarlı ve Baysal (n 7) 129; Senyen Kaplan (n 42) 19; Centel (n 10) 72; Yiğit (n 10) 137; ayrıca Akyiğit (n 17) 117.

Nitekim Yargıtay da işçinin sadece işverenin bir projesinde çalıștırılması kaydıyla işe alınması durumunda projeye bağlı olarak iş sözleșmesinin de belirli süreli yapılmasının mümkün olduğu yönünde kararlar vermektedir. Yargıtay 22 HD, 16097/18567, 21.06.2016. Yine başka bir kararında da AVM projesi bazında belirli süreli işs sözleşmesi başlıklı iş sözleşmesi imzalayarak aynı tarihte davalı işverenler nezdinde inşaat mühendisi olarak çalışmaya başladı̆̆ı, taraflar arasındaki sözleşmenin projenin tamamlanması ile sona ereceğinin kararlaştırıldığı bir sözleşmede, sözleşme süresinin 22 ay olduğunun belirtilmesine rağmen projede kesin hesap ve hakedişler ile ilgili çalışmaların devam ediyor olması nedeni ile zeyilnameler düzenlenerek en son 30.11.2011 olarak sözleşmenin sona erme tarihinin değiştirildiği ve davacının iş akdinin proje bitim tarihi itibari ile 30.11.2011 tarihinde sona erdirildiğinin görüldüğü bir olayda da proje kapsamında işçinin belirli süreli iş sözleşmesi ile çalıştığı sonucuna ulaşmıştır. Yargıtay $22 \mathrm{HD}, 25587 / 24390,24.12 .2019$.

Ayrıca Yargıtay, belirli süreli iş sözleşmelerinin yenilenmesi bakımından da projenin tamamlanmasını objektif bir neden olarak değerlendirmiştir. İşçinin proje bazlı olarak belirli süreli iş sözleşmesi ile çalıștığı sonucuna ulaștığı kararda, her ne kadar ard arda belirli süreli iş sözleşmeleri yapılmış olsa da projenin niteliği gereği belirli bir süre devam etmesi için esaslı neden mevcut olduğundan belirli iş sözleşmesinin yenilenmesi mümkün olacağı kanaatine ulaşmıştır. Yargıtay 22 HD, 7348/21243, 14.11.2019.

48 YİBGK, 10/1, 08.03.2019; Süzek (n 9) 241.

49 Eyrenci, Taşkent ve Ulucan (n 8) 72; Ulucan, ‘4857 Sayılı Kanun' (n 35) 42; Güven ve Aydın (n 10) 103. 


\section{Belirli Bir Olgunun Ortaya Çıkması}

İş Kanunu m. 11 hükmü uyarınca belirli süreli iş sözleşmesi yapılmasına imkân veren bir diğer objektif neden, "belirli bir olgunun ortaya çıkması"dır. Bu ifade, genel ve soyut olup birçok hâlde belirli bir olgunun ortaya çıktı̆̆ kabul edilebilir. Ancak ortaya çıkan olgunun İş Kanunu m. 11 hükmü kapsamında objektif neden oluşturması için belirli süreli iş sözleşmesi yapılmasını haklı kılacak bir nedenin olmasi gerekmektedir ${ }^{50}$. Örneğin, işçinin belirli bir yaşa gelmesi olgusu sözleşmenin sürelendirmesini haklı kılamaz ${ }^{51}$.

İşyerinde, işletmenin normal faaliyetine dâhil olmayan veya sürekli devam etmekte olan mutat durumun dışında ortaya çıkan bir olgu, geçici olarak iş gücü ihtiyacına neden olduğu takdirde belirli süreli iş sözleşmesi yapılabilecektir. Hastalık, hamilelik veya herhangi başka bir durum nedeniyle izinli olan ve iş sözleşmesi askıya alınan işçinin yerine, bir süre için başka bir işçiyle belirli süreli sözleşme yapılması bu bağlamda verilen örneklerdir ${ }^{52}$. Yine geçici bir süreyle işletme kapasitesinin üstünde, olağan durum olarak nitelendirilemeyecek ölçüde iş yoğunluğunun artması veya acil bir sipariş işinin ortaya çıkması da belirli süreli işs sözleşmesi yapılmasına imkân vermektedir ${ }^{53}$.

\section{Objektif Neden Kabul Edilen Benzer Durumlar}

Yukarıda da belirtildiği üzere, İş Kanunu m. 11 hükmünün lafzında objektif nedenler sayıldıktan sonra, "gibi" ifadesine yer verilmesi ile, benzer hâllerde de belirli süreli iş sözleşmesi yapılması mümkün olmaktadır ${ }^{54}$.

Doktrinde, işin ve işyerinin nitelikleri dikkate alınarak sahne sanatları ile ilgili bir işlerle meşgul olan kimselerle yapılan iş sözleşmeleri bu kapsamda görülmektedir ${ }^{55}$. Yargitay da teknik adam (antrenör) ile sezonluk olarak yapılan iş sözleşmelerinde objektif nedenin mevcut olduğunu kabul etmektedir ${ }^{56}$.

50 YİBGK, 10/1, 08.03.2019; Başterzi, 'Avrupa Birliği Konseyi' (n 10) 134-135; Bozkurt Gümrükçüoğlu, Belirli Süreli İ̧̧ Sözleşmesi (n 9) 213-214.

51 Başterzi, ‘İş İlişkisinin Kurulması'’ (n 30) 63; Başterzi, ‘Avrupa Birliği Konseyi’ (n 10) 134.

52 YİBGK, 10/1, 08.03.2019; Süzek (n 9) 242; Çelik, Caniklioğlu ve Canbolat (n 9) 194; Canbolat (n 9) 195; Sümer, Işs Hukuku Uygulamaları (n 10) 46; Güler (n 10) 44; Güzel, Özkaraca ve Ugan (n 9) 540; Mollamahmutoğlu, Astarlı ve Baysal (n 7) 129; Centel (n 10) 72; Akyiğit (n 17) 118.

53 Süzek (n 9) 242; Çelik, Caniklioğlu ve Canbolat (n 9) 194; Eyrenci, Taşkent ve Ulucan (n 8) 73; Ulucan, '4857 Sayılı Kanun' (n 35) 42; Mollamahmutoğlu, Astarlı ve Baysal (n 7) 129; Alpagut, '4857 Sayılı Yasa' (n 10) 80; Başterzi, 'İş İlişkisinin Kurulması' (n 30) 63; Güzel, Özkaraca ve Ugan (n 9) 540; Sümer, İş Hukuku Uygulamaları (n 10) 46; Bozkurt Gümrükçüoğlu, Belirli Süreli İş Sözleşmesi (n 9) 215; Senyen Kaplan (n 42) 19; Centel (n 10) 72; Güven ve Aydın (n 10) 103; Yiğit (n 10) 139; ayıca Akyiğit (n 17) 118.

54 YïGK, 10/1, 08.03.2019.

55 Süzek (n 9) 241; Alpagut, ‘4857 Sayılı Yasa' (n 10) 81; Bașterzi, 'Avrupa Birliği Konseyi’ (n 10) 168 vd; Güzel, Özkaraca ve Ugan (n 9) 541; Yiğit (n 10) 141. Doktrinde, profesyonel sporcularla belirli süreli iş sözleşmesi yapılması da benzer gerekçelerle kabul edildiği ifade edilmekle birlikte profesyonel futbolcuların İş Kanunu kapsamı dışında kalmaları (m. 4/1, g) ve TBK'ye tabi olmaları sonucunda iş sözleşmelerinin ilk defa yapılmasında objektif neden aranmayacaktır. Krş Başterzi, ‘Avrupa Birliği Konseyi’ (n 10) 170 vd; Güzel, Özkaraca ve Ugan (n 9) 541.

56 Yargitay 9 HD, 26411/490, 04.06.2018; Yargitay 9 HD, 16505/6610, 29.06.2020. 
İstihdam politikaları sonucunda geliştirilen programlarda işçi çalıştırırken de belirli süreli iş sözleşmesi yapılması haklı görülmektedir. Örneğin Aktif İsgücü Hizmetleri Yönetmeliği ${ }^{57} \mathrm{~m}$. 40 hükmü gereği, Türkiye İş Kurumu'nun düzenlediği meslek edindirme, geliştirme ve değiştirme eğitimlerine ilişkin kurslara katılan kursiyerlere belli süre istihdam imkânı yaratılması zorunludur. Bu zorunluluk, Kurum'un hizmet aldığı yüklenicilere ait olup belirli süre için söz konusudur ${ }^{58}$. Bunun sonucunda da, istihdam edilen kursiyerler ile yapılan işs sözleşmelerinin sürelendirilmesi haklı kabul edilmektedir ${ }^{59}$.

\section{Diğer Kanunlardan Kaynaklanan Belirli Süreli İş Sözleșmeleri}

İş Kanunu m. 11 hükmü dışında, özel kanunlarda belirli süreli iş sözleşmesi yapılmasına imkân veren düzenlemeler bulunmaktadır. Sözleşmenin belirli süreli yapılması gerektiğinin kanun tarafından öngörüldüğü durumlarda objektif koşulun gerçekleştiği kabul edilmekte ${ }^{60}$; ayrıca objektif neden bulunması aranmamaktadır ${ }^{61}$.

Belirli süreli iş sözleşmesi yapılmasına imkân veren kanunlardan biri, 5580 sayılı Özel Öğretim Kurumları Kanunu'dur ${ }^{62}$. Bu Kanun kapsamındaki kurumlarda çalışan öğretmen, yönetici, uzman öğretici ve usta öğretici ile işveren arasında yapılan iş sözleşmesinin "en az bir takvim yılı süreli” olarak yapılması öngörülmüştür (m. 9) ${ }^{63}$. Süreye ilişkin bu ifade, Yargıtay daireleri arasında farklı kararların ortaya çıkmasına sebep olmuştur. Esasını iş sözleşmesinin asgari süreli mi yoksa belirli süreli mi olduğu oluşturan karar farklılıkları sonucunda, içtihadı birleştirme yoluna gidilmiştir. Yargitay İçtihatları Birleştirme Genel Kurulu'nun 23.02.2018 tarihinde verdiği karar $^{64}$ ile kanun hükmü gereği yapılan iş sözleşmelerinin niteliğinin belirli süreli iş sözleşmesi olduğu ve ne kadar yenilenirse yenilensin bu niteliğin korunacağı açıklığa

57 RG 12.03.2013/28585.

58 Yönetmeliğin 40. maddesine göre; “Kursiyerlerin en az yüzde ellisi, kurs sınav sonucunun açıklandı̆̆ı tarihten itibaren en geç otuz gün içinde işe başlatılmak şartı ile yüz yirmi günden az olmamak üzere en az fiili kurs günü kadar istihdam edilir (f. 1). İstihdam yükümlülüğ̈̈nün yerine getirilmesi yüklenicinin sorumluluğundadır (f. 3).”.

59 Aktif İşgücü Hizmetleri Yönetmeliğinin yürürlükten kaldırdığı Türkiye İş Kurumu İşgücü Uyum Hizmetleri Yönetmeliği (RG 31.12.2008/27097, 6. Mük.) hakkında aynı yönde değerlendirmeler için bkz Başterzi, 'Avrupa Birliği Konseyi’ (n 10) 150-151; Bozkurt Gümrükçüoğlu, Belirli Süreli İ̧ Sözleşmesi (n 9) 230.

60 YİBGK, 10/1, 08.03.2019; Sümer, 'Özel Öğretim Kurumu Öğretmenleri' (n 10) 429; Mollamahmutoğlu, Astarlı ve Baysal (n 7) 130, Centel (n 10) 72 .

${ }^{61}$ YİBGK, 10/1, 08.03.2019; Süzek (n 9) 244; Alpagut, '4857 Sayılı Yasa' (n 10) 84; Güler (n 10) 45.

${ }_{62}$ Kabul Tarihi: 08.02.2007, RG 14.02.2007/26434. 5580 sayılı Kanun ile objektif neden öngörülmesinin yasal düzenlememiz ve yargı kararlarınca oluşturulan sistemin bütünlüğü ile uyumsuz olduğu ve bunun yanında yasal düzenlemenin temel dayanağı olan Avrupa Birliği Direktifi, Çerçeve Antlaşma ve ABAD kararlarına aykırılık teşkil ettiği; dolayısıyla bu kanundaki düzenlemelerin yürürlükten kaldırılması gerektiği yönünde, Güzel, Özkaraca ve Ugan (n 9) 540.

63 Sözleşmenin niteliğine ilişkin ilişkin doktrindeki değerlendirmeler için bkz Tankut Centel, 'Özel Okul Öğretmeniyle Sözleşme Yapılması’ (2007) 6 Sicil Dergisi 22, 23; Sümer, ‘Özel Öğretim Kurumu Öğretmenleri’ (n 10) 435-436; Yeliz Bozkurt Gümrükçüoğlu, '5580 Sayılı Özel Öğretim Kurumları Kanunu Kapsamında Yapılan Zincirleme İş Sözleşmesinin Sona Ermesinde Kıdem Tazminatı’ (2016) 74 (Özel Sayı) İstanbul Üniversitesi Hukuk Fakültesi Mecmuası (Prof. Dr. Fevzi Şahlanan'a Armağan) 223, 232 vd; Yeliz Bozkurt Gümrükçüoğlu ve Beste Gemici Filiz, 'Yargıtay Kararları Işı̆̆ında Özel Okul Öğretmenleri ile Yapılacak İș Sözleşmelerinin Türüne İlişkin Bir Değerlendirme’ (2016) 15 (1-2) İstanbul Kültür Üniversitesi Hukuk Fakültesi Dergisi 369, 370-401.

${ }^{64}$ YİGK, 1/2, 23.02.2018. 
kavuşturulmuştur. Karar metninde; "5580 Sayılı Özel Öğretim Kurumları Kanunu kapsaminda çalı̧̧anların iş sözleşmelerinin üst üste yenilense dahi bu yenilenmenin yasadan kaynaklandiğl ve sözleşmenin belirli süreli iş sözleşmesi olma özelliğini koruduğuna" yer verilmiștir.

Belirtelim ki, belirli süreli iş sözleşmesi yapılmasına imkân veren düzenlemenin 5580 sayılı Kanun'da bulunması, kanun kapsamında olan öğretmen, yönetici, uzman öğretici ve usta öğreticinin işçi niteliğini değiştirmez. Aksine 5580 sayılı Kanun m. 9 hükmünde de açıkça belirtildiği üzere, kurumlarda çalışan öğretmen, yönetici, uzman öğretici ve usta öğreticiler özlük hakları yönünden İş Kanunu'na tabidirler.

Yargitay 22. Hukuk Dairesi de 2020 yılında verdiği bir kararda ${ }^{65}$, somut olaydaki uyuşmazlığın bulunduğu dönemde 5580 sayılı Kanun kapsamında olan etüt merkezinde iş sözleşmesi ile çalışan öğretmenin açtığ davada şu değerlendirmeleri yapmıştı: "Somut uyuşmazlıkta, sözleşmenin belirli süreli olarak yapılması kanuni düzenlemenin bir gereğidir. Aynı şekilde sözleşmenin yenilenmesi, sözleşmeyi belirsiz süreli hale getirmez. Bu tür sözleşmelerde, İ̧̧ Kanunu'nun 11/3 maddesindeki esasl nedenin kendiliğinden mevcut olduğu kabul edilmelidir.".

\section{Belirli Süreli İş Sözleşmesinde Objektif Neden Bulunmamasının Sonuçları}

\section{1. İş Sözleşmesinin İlk Defa Yapılmasında}

İş Kanunu'nun 11. maddesinin ilk fikrasında belirli süreli iş sözleşmesinde objektif neden koşuluna açıkça yer verilmesine rağmen ne bu fikrada ne de başka bir yerde, objektif neden bulunmamasına rağmen yapılan belirli süreli iş sözleşmelerine uygulanacak yaptırıma ilişkin bir açıklık bulunmaktadır ${ }^{66}$.

Yargıtay içtihatlarında ve doktrinde hâkim görüş tarafindan objektif neden yokken yapılan belirli süreli iş sözleşmeleri, belirsiz süreli iş sözleşmesi olarak

\footnotetext{
5 Yargitay $22 \mathrm{HD}, 30164 / 6705,15.06 .2020$.

${ }_{66}$ Doktrinde Ekonomi ve Bozkurt Gümrükçüoğlu tarafından belirli süreli işs sözleşmesinin yenilenmesine ilişkin İş Kanunu m. 11/2 hükmündeki açık hüküm gibi, belirli süreli iş sözleşmesinin ilk defa kurulmasında da objektif koșulun bulunmamasının bu sözleşmeyi belirsiz süreli iş sözleşmesine dönüştüreceğinin açıkça düzenlenmesi gerektiği savunulmuştur, Münir Ekonomi, '4857 Sayılı Kanun Hükümlerine Göre Belirli Süreli İş Sözleşmesinin Hukuka Uygunluğu (I) Kavram Süre ve Yenileme’ (2006) 3 (9) Legal İHSGHD 15, 19; Bozkurt Gümrükçüoğlu, Belirli Süreli İş Sözleşmesi (n 9) 266. Alp de, yaptırıma ilişkin açık bir düzenleme yapılması gerektiğini savunmakla birlikte, yazara göre yasal değişiklik ile sözleşmenin belirsiz süreli iş sözleșmesine dönüștügünün sadece ișçi tarafindan ileri sürülebileceği öngörülmelidir, Alp, Mustafa: "İş İlişkisinin Sona Ermesi ve Kıdem Tazminatı Açısından Yargıtayın 2013 Yı1ı Kararlarının Değerlendirilmesi”, Yargıtay'ın İş Hukuku ve Sosyal Güvenlik Hukuku Kararlarının Değerlendirilmesi 2013, İstanbul, 2015, 184; Mustafa Alp, 'Belirli Süreli İş Sözleşmesinin Yargıtay Tarafından Resen Belirsiz Süreli İş Sözleşmesinde Dönüştürülmesi’ iç Kübra Doğan Yenisey (ed), Prof. Dr. Savaş Taşkent'e Armağan (On İki Levha 2019) 477, 492.
} 
kabul edilmektedir ${ }^{67}$. Ancak bu durumun işveren tarafından ileri sürülmesi ile hâkim tarafından resen dikkate alınıp alınmayacağı konusu önemli tartışmalara neden olmuştur.

Öncelikle Yargıtay'ın içtihatlarının gelişimi incelenecek olursa ${ }^{68}$; Yargıtay 9. Hukuk Dairesi ve Hukuk Genel Kurulu kararları ile 22. Hukuk Dairesi’nin kiyasen eski tarihli kararlarında ${ }^{69}$; objektif neden bulunmamasına rağmen sürelendirilen iş sözleşmeleri, belirsiz süreli iş sözleşmesi olarak kabul edilmiş ve bu nedenle işçinin bakiye süre ücreti isteyemeyeceğine hükmedilmiş olduğu görülecektir. Yargıtay'ın söz edilen içtihatlarında belirli süreli olarak kurulan iş sözleşmelerinde objektif neden bulunmaması hâlinde mahkemenin resen sözleşmeyi belirsiz süreli iş sözleşmesi olarak nitelendirmesi gerektiğine karar verilmekte idi.

Yüksek Mahkemenin bu kararları, doktrin tarafından eleştirilmiştir ${ }^{70}$. Belirli süreli iş sözleşmesinin ilk defa yapılmasında objektif nedenin bulunmasını gerekli kılan İş Kanunu m. 11/1 hükmünün "işçiyi” koruma amacını taşıdığından yola çıan yazarlar, bu korumadan sadece işçinin yararlanabileceğini, yani objektif nedenin yokluğunda iş sözleşmesinin belirsiz süreli olduğunu sadece işçinin ileri sürebileceğini savunmaktadırlar ${ }^{71}$. Bahsedilen görüşs sahiplerine göre; işverenin bu

67 Yargıtay 7 HD, 804/7233, 28.03.2016; Yargıtay 22 HD, 19958/24680, 13.11.2017; Bozkurt Gümrükçüoğlu, Belirli Süreli İs Sözleşmesi (n 9) 266; Doğan Yenisey K, İş Hukukunun Emredici Yapısı (1. Bası, Beta 2014) 313; Sümer, İs Hukuku Uygulamaları (n 10) 49; Güler (n 10) 48; benzer yönde, Ekonomi, ‘4857 Sayılı Kanun’ (n 66), 20. Belirtelim ki, yukarıda değinilen belirli süreli iş sözleşmesinin ilk defa yapılmasında kanun gereği objektif neden aranmadığını savunan azınlık görüşü sahiplerince bu görüş ile tutarlı olarak, belirsiz süreli iş sözleşmesine dönüşme yaptırımının uygulanamayacağı ileri sürülmüştür, Taşkent (n 9) 20.

68 Yargıtay içtihatlarının gelişimine ilişkin kapsamlı bir inceleme için bkz Alp, 'Belirli Süreli' (n. 66) 477 vd.

69 Yargitay 22 HD, 34840/9084, 05.03.2015; Yargitay 9 HD, 7189/11509, 07.04.2014; Yargitay 9 HD, 26037/18826, 22.10.2018; Yargitay HGK, 9-2514/13; 18.01.2017. Direnme yoluyla Hukuk Genel Kurulu'nun önüne gelen ve karara konu olan uyuşmazlık, davacı işçi ile davalı işveren arasında yapılan iş sözleşmesinin başlangıçtan itibaren belirli süreli iş sözleşmesinin unsurlarını taşıyıp taşımadığı, bu bağlamda sözleşmenin belirli süreli iş sözleşmesi mi yoksa belirsiz süreli iş sözleşmesi mi olduğu, varılacak sonuca göre davacının bakiye süre yönünden ücret alacağı talebinde bulunup bulunamayacağı noktasında toplanmaktadır. Karar metninde direnme kararı veren mahkemenin gerekçesinin taraflar arasındaki sözleşmenin belirli süreli iş sözleşmesi olarak yapıldığı, her iki tarafın da sözleşmenin imzalanması sırasında iradelerinin hataya uğradığını iddia etmediği, gerek yargılama aşamasında gerekse temyiz dilekçesinde sözleşmenin belirsiz süreli olduğuna dair herhangi bir iddia ve beyanda bulunulmadığı, işveren tarafından dahi iddia edilmeyen bir hususun işçi lehine yorum ilkesine ters düşecek şekilde değerlendirilerek, yanlar arasındaki sözleşmenin belirsiz süreli iş sözleşmesi olarak kabul edilemeyeceği olduğu belirtilmiştir. HGK ise, taraflar arasındaki iş ilişkisi objektif koşullara bağlı bulunmadığından sözleşmenin başlangıçtan itibaren belirsiz süreli sayılması gerektiği ve belirsiz süreli işs sözleşmesinde ise bakiye süre ücreti gerçekleşmeyeceği şeklinde hüküm vermiştir.

70 Doğan Yenisey, İş Hukukunun Emredici Yapısı (n 67) 376-377; Süzek (n 9) 246-247; Başterzi, 'İş İlişkisinin Kurulması' (n 30) 80; Başterzi, 'Objektif Neden' (n 10) 443 vd; Can Tuncay, 'İș İlişkisinin Kurulması, Hükümleri ve İşin Düzenlenmesi Açısından Yargıtayın 2011 Yılı Kararlarının Değerlendirilmesi’ (2013) Yargıtayın İş Hukuku ve Sosyal Güvenlik Hukuku Kararlarının Değerlendirilmesi 2011, 1, 46; Alp, Değerlendirme, 182 vd; Alp, 'Belirli Süreli' (n. 66) 488-489; Bozkurt Gümrükçüoğlu, Belirli Süreli İş Sözleşmesi (n 9) 266; Mahmut Kabakçı, 'Belirli Süreli İş Sözleşmesinin Geçersizliğinin İşçi ve İşveren Açısından Farklı Değerlendirilmesi Gereği’ (2014) 72 (2) İÜHFD (Prof. Dr. Berin Ergin’e Armağan) 123, 123 vd; Gaye Baycık, 'İş İlişkisinin Kurulması, Hükümleri ve İşin Düzenlenmesi Açısından Yargıtayın 2016 Yı1ı Kararlarının Değerlendirilmesi' (2018) Yargıtay'ın İş Hukuku ve Sosyal Güvenlik Hukuku Kararlarının Değerlendirilmesi 2016, 7, 161 vd; Ekmekçi ve Yiğit (n 34) 39.

71 Doğan Yenisey, İş Hukukunun Emredici Yapısı (n 67) 376-377; Süzek (n 9) 247; Tuncay, 'İş İlişkisinin Kurulması' (n 70) 46-47; Alp, 'Belirli Süreli' (n. 66) 488; Bozkurt Gümrükçüoğlu, Belirli Süreli İş Sözleşmesi (n 9) 266; Baycık, 'İş İlişkisinin Kurulması' (n 70) 162-163. 
korumadan faydalanması dürüstlük kuralı ile bağdaşmayacağ $1^{72}$ gibi objektif nedenin yokluğunun hâkim tarafindan resen dikkate alınması da kanun koyucunun amacı ile ters düşmektedir ${ }^{73}$.

Yargıtay 22. Hukuk Dairesi isabetli olarak, hükmün amacına aykırı olan bu içtihadı terk etmiştir. Özel Daire, 2017 y1lında verdiği kararda ${ }^{74}$, belirli süreli iş sözleşmesi ile çalışan işçilerin belirsiz süreli iş sözleşmesi ile çalışan işçilere göre daha az koruma altında olduğu düşüncesinden hareket etmiştir. Bu düşünce uyarınca, iş sözleşmesinin belirsiz süreli olmasının asıl, belirli süreli olmasının ise istisna olarak düzenlendiğini ve bu yaklaşımın iş̧̧inin korunması amacına matuf olduğunu belirten Özel Daire, davalı işverence objektif neden yokluğunun ve dolayısıyla sözleşmenin belirsiz süreli olduğunun ileri sürülmesi hâlinde işçinin korunması amacını taşıyan düzenlemenin aksine sonuç doğacağına işaret etmiştir. Kararda bu şekilde bir uygulamanın kanunun amacına aykırı olacağı gibi hakkın kötüye kullanılması niteliğinde olduğu belirtilmektedir. Yüksek Mahkeme kararda işverence iş sözleşmesinin belirsiz süreli olduğuna dair bir savunma yapılmadığına da değindikten sonra işçiyi korumaya yönelik düzenlemenin işveren lehine değerlendirilemeyeceğini vurgulamış ve mahkemece objektif neden bulunmadığı, iş sözleşmesinin belirli süreli olmadığından bahisle davaya konu bakiye süre ücreti talebinin reddinin isabetli olmadığı sonucuna ulaşmıştır. Söz konusu kararda Özel Daire içtihat değişikliğini "Her ne kadar Dairemizce, benzer nitelikli davalarda, aksine kararlar verilmiş ise de, konunun yeniden değerlendirilmesi neticesinde, anılan içtihadın değiş̧tirilmesi gerektiğ sonucuna varılmıştır." şeklindeki ifade ile açıkça ifade etmiştir.

Yargıtay 22. Hukuk Dairesi 2019 tarihli başka bir kararında ${ }^{75}$ da benzer yönde değerlendirmelerde bulunmuş ve sözleşmenin belirsiz süreli olduğunu ileri sürme hakkının sadece işçiye ait olduğu sonucuna ulaşmıştır. Söz konusu karara göre, "İ̧̧ Kanunun 11. maddesinde öngörülen hükmün işçiyi koruma amacıyla düzenlendiği dikkate alınarak, objektif şartlar bulunmadiğ halde belirli süreli olarak yapılmış olan işs sözleşmesinin, belirsiz süreli olduğunun işveren tarafindan ileri sürülmesinin Türk Medeni Kanunu'nun 2. maddesi uyarınca hakkın kötüye kullanımını teşkil ettiği, İ̧ Kanunu'nun 11. maddesine dayanarak sözleşmenin belirsiz süreli olduğunu ileri sürme hakkının sadece işçiye ait olması gerektiği anlaşılmıştır. Öte yandan, normun sosyal koruma amacl göz önünde bulundurulduğunda, işçinin bakiye süre

72 Doğan Yenisey, İş Hukukunun Emredici Yapısı (n 67) 376-377; Süzek (n 9) 246; Başterzi, 'İş İlişkisinin Kurulması' (n 30) 80; Başterzi, 'Objektif Neden' (n 10) 443-444; Tuncay, 'İş İlişkisinin Kurulması' (n 70) 46; Alp, Değerlendirme, 183; Alp, 'Belirli Süreli' (n. 66) 488-489; Kabakç1, (n 70) 140-141; Bozkurt Gümrükçüoğlu, Belirli Süreli İş Sözleşmesi (n 9) 266; Baycık, 'İş İlişkisinin Kurulması' (n 70) 162-163 Ekmekçi ve Yiğit (n 34) 39.

73 Doğan Yenisey, İş Hukukunun Emredici Yapısı (n 67) 376-377; Tuncay, 'İș İlişskisinin Kurulması' (n 70) 46-47; Alp Değerlendirme, 182; Alp, 'Belirli Süreli' (n. 66) 491-492; Baycık, 'İș İlișkisinin Kurulması' (n 70) hâkimin objektif nedeni resen araştırmasının hak arama özgürlüğünü de ihlal edebileceği yönünde, Başterzi, 'Objektif Neden' (n 10) 447, 449.

${ }^{74}$ Yargıtay 22 HD, 20653/30350, 21.12.2017; içtihat değişikliğini isabetli bulan görüş için bkz Alp, 'Belirli Süreli' (n. 66) 499.

75 Yargıtay 22 HD, 9582/9316, 22.04.2019; benzer kararlar için bkz Yargıtay 22 HD, 29143/2773, 18.02.2020; Yargıtay 22 HD, 34697/9344, 09.07.2020. 
ücreti tutarl tazminat veya cezai şart talebi ile açtı̆̆ bir davada, mahkemece objektif nedenin bulunmadı̆̆ının resen gözetilerek sözleşmenin belirsiz süreli olduğunun kabulü de yerinde değildir." ${ }^{\prime 6}$.

Yargıtay 22. Hukuk Dairesi'nin kapatılmasının ${ }^{77}$ ardından iş hukuku uyuşmazlıklarında görevli tek daire hâline gelen 9. Hukuk Dairesi tarafından verilen kararda da aynı doğrultuda tespitlere yer verilmiştir ${ }^{78}$.

Belirli süreli olarak yapılan iş sözleşmelerinde objektif nedenin bulunmaması, sözleşmede süreden önce haksız feshe bağlanan bir cezai şartın belirlenmiş olması hâlinde ayrıca önem kazanmaktadır. Bu durumda cezai şartın akıbeti, Yargıtay'ın daireleri arasında içtihat farklılıklarına yol açmış olup konu hakkında içtihadı birleştirme kararı verilmesi gerekmiştir ${ }^{79}$. Yargıtay İçtihadı Birleştirme Genel Kurulu'nun 2019 yılında verdiği karara göre, objektif nedenin bulunmaması yüzünden belirsiz süreli olarak kabul edilen iş sözleşmelerinde "süreden önce haksız feshe bağlı cezai şart" hükmünün yer alması hâlinde, bu hüküm belirlenen süre ile sınırlı olarak geçerlidir ${ }^{80}$.

\section{Belirli Süreli İş Sözleşmesinin Yenilenmesinde}

\section{a. İş Kanunu kapsamındaki iş iliş̧kilerinde}

İş Kanunu'nun 11. maddesinin 2. fikrasında belirli süreli iş sözleşmesinin esaslı bir neden olmadıkça, birden fazla üst üste (zincirleme) yapılamayacağ 1 belirtildikten sonra aksi hâlde iş sözleşmesi başlangıçtan itibaren belirsiz süreli kabul edileceğine yer verilmiştir. Bu düzenleme uyarınca; belirli süreli iş sözleşmesinin yenilenmesinde ikinci ya da daha sonraki sözleşmenin yapılması sırasında objektif nedenin bulunmaması hâlinde, iş sözleşmesi başlangıçtan itibaren belirsiz süreli iş sözleşmesine dönüşecektir ${ }^{81}$.

76 Aynı yönde, Yargıtay 22 HD, 36844/7827, 25.06.2020; Yargıtay'ın bu yöndeki kararları doktrinde isabetli bulunmuştur. Bkz Ekmekçi ve Yiğit (n 34) 39.

77 07.07.2020 tarihli ve 173 sayılı Yargıtay Birinci Başkanlık Kurulu Kararı ile 22. Hukuk Dairesi’nin 02.09.2020 tarihinden itibaren geçerli olmak üzere kapatılmasına karar verilmiştir. RG 08.07.2020/31179.

78 Yargitay 9 HD, 22178/7846, 15.09.2020.

79 Sümer, İș Hukuku Uygulamaları (n 10) 180-181; İrem Yayvak Namlı, İs Hukuku’nda Cezai Şart (1. Bası, On İki Levha 2019) 398 vd; Hakan Keser, 'Objektif Sebep Olmaksızın Yapılan Belirli Süreli İş Sözleşmesinde Düzenlenmiş Cezai Şartın Geçerliliğinin Yargıtay İçtihadı Birleştirme Büyük Genel Kurulu Kararı Kapsamında Değerlendirilmesi’ (2020) 43 Sicil Dergisi $30,40 \mathrm{vd}$.

80 YIBBGK 08.03.2019, E. 2017/10, K. 2019/1, RG 18.07.2019/30835; kararı isabetli bulan değerlendirmeler için bkz Yayvak Namlı (n 79) 409-410; Keser (n 79) 45 vd, özellikle 50-51.

${ }^{81}$ Nitekim Yargıtay 9. Hukuk Dairesi de 11.03.2020 tarihli kararında taraflar arasındaki iş sözleşmesinin 18.11.2013 tarihinde bir yıl süreli olarak imzalandığı, bu sözleşmenin süresi dolmadan 30.01.2014 tarihinde hiçbir objektif ve esaslı bir neden gösterilmeksizin 18.11.2014-17.11.2017 tarihlerini kapsayacak şekilde ikinci kez sözleşme imzalandığ1 somut olayda, İş Kanunu m. 11/2 hükmü gereği iş sözleşmesinin başlangıçtan itibaren belirsiz süreli hâle geldiğini belirtmiştir. Mahkemece, iş sözleşmesinin belirsiz süreli olduğunun kabulüyle davacının bakiye süre ücreti talebinin reddi gerekirken yanılgılı değerlendirme ile talebin kabulüne karar verilmesi hatalı bulunmuştur. Yargıtay 9 HD, 16212/4115, 11.03.2020. 
Belirtelimki, maddenin lafzı açık olup belirli süreli iş sözleşmesi yenilenmesinde objektif neden bulunmadığ 1 takdirde, sözleşmenin ilk defa yapıldığında ve/veya sözleşmeler zincirinde önceki yenilemelerde objektif nedenin varlığı sonucu değiştirmeyecektir ${ }^{82}$.

\section{b. Türk Borçlar Kanunu kapsamındaki iş ilişkilerinde}

Belirli süreli iş sözleşmesinde sözleşmesinin sona ermesini düzenleyen TBK m. 430 hükmünün 2. fikrasında göre, "Belirli süreli sözleşme, süresinin bitiminden sonra örtülü olarak sürdürülüyorsa, belirsiz süreli sözleşmeye dönüşür. Ancak, esaslı bir sebebin varlı̆̆l hâlinde, üst üste belirli süreli hizmet sözleşmesi kurulabilir.”.

Görüldügü üzere, TBK'de belirli süreli iş sözleşmesinin yenilenmesi sırasında objektif nedenin bulunmaması hâli, İş Kanunu m. 11 hükmü ile benzer düzenlenmiş; iş sözleşmesinin başlangıçtan itibaren belirsiz süreli iş sözleşmesine dönüşmesi sonucuna bağlanmıştır.

Ayrıca aynı fikrada süresi dolan sözleşme ilişkisinin devam ettirilmesi durumunda sözleşmenin belirsiz süreli iş sözleşmesine dönüşeceği belirtilmiştir. Bu yaklaşımın olağan bir sonucuna aynı maddenin 3. fikrasında yer verilmiştir ${ }^{83}$. Söz konusu fikraya göre, "Sözleşmenin fesih bildirimiyle sona ereceği kararlaştırılmış ve iki taraf da fesih bildiriminde bulunmamışsa, sözleşme belirsiz süreli sözleşmeye dönüşür." 84 .

\section{c. Basın İș Kanunu kapsamındaki iș ilișkilerinde}

Basın İş Kanunu kapsamındaki iş ilişkileri bakımından belirli süreli iş sözleşmesinin yapılmasında ve yenilenmesinde kanunda özel bir düzenleme bulunmaması sebebiyle, yukarıdaki başlıkta TBK kapsamındaki iş ilişkileri bakımından açıklanan esaslar, gazeteciler bakımından da uygulanacaktır.

\section{d. Deniz İş Kanunu kapsamındaki iş ilişkilerinde}

Deniz İş Kanunu kapsamındaki iş ilişkileri bakımından belirli süreli iş sözleşmesinin yapılmasında m. 7 hükmü ile objektif neden aranmamıştır. Belirli süreli iş sözleşmesinin yenilenmesinde ise TBK m. 430 hükmü dikkate alınmakta ve objektif neden aranmıştır. Yargıtay 9. Hukuk Dairesi tarafından sefer kaydı objektif neden olarak ifade edilmektedir ${ }^{85}$. Aynı Daire çeşitli kararlarında, birden fazla yenilenen iş sözleşmesinin, sürenin sefere bağlanmadığı, daha önce de sözleşme

\footnotetext{
82 Alpagut, '4857 Sayılı Yasa' (n 10) 85; Bozkurt Gümrükçüoğlu, Belirli Süreli İş Sözleşmesi (n 9) 268.

83 Doğan Yenisey, 'Hizmet Sözleşmesi' (n 12) 326.

${ }^{84}$ Bu fikranın mülga 818 sayılı Borçlar Kanunundaki çeviri hatasının devamı olduğu ve belirli süreli iş sözleşmesinin fesih bildirimi ile sona ermesinin kararlaștırılması sözleșmenin "belirli süreli" olması ile bağdașmayacağından hareketle fesih bildirimi ile kastedilenin sözleşmenin yenilenmeyeceğine ilişkin ihbar olduğu yönünde açıklamalar için bkz Soyer, 'Hizmet Sözleşmesi' (n 12) 13; Doğan Yenisey, 'Hizmet Sözleşmesi' (n 12) 326.

${ }^{85}$ Yargitay 9 HD, 22725/5978, 14.03.2016.
} 
sürelerinden önce sözleşmenin bittiği, çalışma süresi dikkate alındığında TBK m. 430 hükmü gereği belirsiz süreli iş sözleşmesine dönüştüğü sonucuna ulaşmıştır ${ }^{86}$.

\section{IV. İș Kanunu m. 11 Hükmüne İlișkin Görüș ve Önerilerimiz}

\section{Mehaz Düzenlemeler Işı̆̆ında Değerlendirme}

Her ne kadar Avrupa Birliği Direktifleri ülkemiz bakımından bağlayıcı olmasa da İş Kanunu'nun yapılması nedenlerinden biri, Türkiye'nin Avrupa Birliği'ne üyelik süreci ve Avrupa Birliği müktesebatına uyumdur. Nitekim İş Kanunu'nun genel gerekçesine göre, "Ülkemizin onayladı̆̆l uluslararası çalışma sözleşmelerinin gereğini yerine getirme çabalarını sürdürürken Avrupa sosyal normlarına da uyum sağlanması gereği ortaya çıkmıştır... Ancak, AB’ne tam üyelik sürecinde Türk mevzuatında henüz bulunmayan, buna karşılık AB ülkelerini kendiliğinden bağlayan normların da Türk iş hukukuna kazandırılması gerekmektedir.’.

$\mathrm{Bu}$ yaklaşıma uygun olarak belirli süreli iş sözleşmelerine ilişkin esasların yer aldığı İş Kanunu m. 11 hükmünün gerekçesinde de, bu düzenlemenin kaynağının Avrupa Konseyi'nin 1999/70 sayılı Direktifi ile yürürlüğe konulan Belirli Süreli İş Sözleşmeleri Hakkında Çerçeve Antlaşma ile Uluslararası Çalışma Örgütü'nün 158 sayılı Sözleşmesi olduğu belirtilmiştir.

Mehaz düzenleme olan Çerçeve Antlaşma, ulusal, sektörel ve dönemsel durumların dikkate alınması gerektiğini kabul ederek belirli süreli iş sözleşmeleri ile ilgili genel ilkeleri ve asgari gereklilikleri belirlemektedir (Giriş kısmı).

İş Kanunu m. 11 hükmünün diğer dayanağı olan 158 sayılı ILO Sözleşmesi ise, iş güvencesine ilişkin olup Sözleşme'de belirli süreli veya belirli bir işin tamamlanmasına yönelik işlerde çalışan işçilerin, sözleşmenin uygulama alanının dışında bırakılabileceği belirtilmiştir. Ancak diğer taraftan, Sözleşme'nin 2. maddesi ile taraf ülkelere işverenlerin işçileri iş güvencesi hükümlerinin dışında bırakma amacıyla belirli süreli iş sözleşmesi yaparak belirli süreli iş sözleşmesi yapma hakkını kötüye kullanmalarını önleyici gerekli tedbirlerin alınması yükümlülüğü yüklenmiştir ${ }^{87}$.

Belirtmek gerekir ki, Çerçeve Antlaşma ile, ilk defa yapılan belirli süreli iş sözleşmelerinin objektif nedene dayanma zorunluluğu bulunmamakta olup norm koyucunun bu yaklaşımının arkasında işsizliği azaltma, işgücünün istihdama geçişini kolaylaştırma çabalarına engel olmamak niyeti olduğu ifade edilmektedir ${ }^{88}$.

\footnotetext{
86 Yargitay 9 HD, 3339/13024, 11.06.2019; Yargitay 9 HD, 906/10082, 07.05.2019; Yargitay 9 HD, 1962/36536, 02.12.2014; Yargitay 9 HD, 1963/36537, 02.12.2014; Yargitay 9 HD, 7792/12652, 29.04.2013; benzer yönde, Yargitay 9 HD, 3655/12648, 29.04.2013; benzer yönde bkz ayrıca İstanbul BAM 28 HD, 3191/164, 13.02.2020.

87 Açıklamalar için bkz Bozkurt Gümrükçüoğlu, Belirli Süreli İş Sözleşmesi (n 9) 157.

88 Güzel, Özkaraca ve Ugan (n 9) 487; Caniklioğlu, ‘Türk Borçlar Kanunu' (n 12) 168.
} 
İş Kanunu m. 11 hükmü, AB müktesebatı ile Birlik üyesi ülkelerdeki yasal düzenlemeler ile kıyaslandığında ise, belirli süreli iş sözleşmelerin ilk defa yapılmasında öngörülen esasların üye ülkelere nazaran daha katı olduğu sonucuna ulaşılmaktadır ${ }^{89}$. Gerçekten birçok Birlik üyesi ülkede, meşru sosyal politika hedeflerine ulaşılması amacıyla belirli süreli iş sözleşmesinin ilk defa yapılmasının objektif neden koşulundan bağışık tutulduğu hâller mevcuttur ${ }^{90}$.

İş Kanunu m. 11 hükmü, belirli süreli iş sözleşmesinin yenilenmesinde de objektif neden koşulunu ararken madde gerekçesinde, bunun Avrupa Birliği müktesebatının da bir gereği olduğu ifade edilmektedir. Gerçekten gerekçede, belirsiz süreli iş sözleşmesi ile çalışan işçilerin sosyal yönden, daha fazla korunduklarının bir gerçek olduğu ifade edildikten sonra bazı işkolları, meslekler ve işler için belirli süreli sözleşmelerin karakteristik bir anlam taşıması ve bu tür sözleşmelerin işletme ve işyeri gereklerinden olmakla beraber, belirli süreli iş sözleşmelerinin kötüye kullanilmasinin engellenmesi ve bunların "objektif temellere" dayandirlmasinin Avrupa Birliği müktesebatının da bir gereği olduğu belirtilmiştir. Bu açıdan da belirli süreli iş sözleşmeleri için, belirli süreli iş sözleşmelerinin objektif bir neden olmadıkça üst üste yapılmalarının önlenmesi de gerektiği vurgulanmıştır.

Belirtmek gerekir ki, Çerçeve Antlaşma ile belirli süreli iş sözleşmelerinin yenilenmesini önlemek amacıyla üye ülkeler için öngörülen seçenek önlemlerden biri olarak objektif neden koşuluna yer verilmiştir. Gerçekten Çerçeve Antlaşma'nın 5. maddesine göre, kötüye kullanmaları önleyici mevzuata sahip olmayan üye devletler, sosyal taraflara danışılmak kaydıyla ulusal yasalarında, toplu iş sözleşmesine ya da uygulamaya uygun olarak, belirli süreli iş sözleşmesinin zincirleme yapılarak kötüye kullanılmasını engellemek amacıyla üç önlemden birini, ikisini ya da üçünü öngörebileceklerdir. Bahsedilen ve seçenek olarak öngörülen üç önlem ise; (a) belirli süreli iş sözleşmelerin yenilenebilmesi için "objektifneden"in bulunması; (b) birbirini takip eden belirli süreli iş sözleşmesinin "azami bir süre” ye bağlanmast ve (c) birbirini takip eden belirli süreli iş sözleşmesinin "azami sayı" sııın belirlenmesidir"11.

89 Başterzi, ‘Avrupa Birliği Konseyi’ (n 10) 185; ayrıca bkz Bozkurt Gümrükçüoğlu, Belirli Süreli İş Sözleşmesi (n 9) 171.

90 Başterzi, ‘Objektif Neden' (n 10) 434; AB hukuku için bkz Güzel ve Ertan, (n 29) 400 vd; Başterzi, 'Avrupa Birliği Konseyi' (n 10) 182-183; Bozkurt Gümrükçüoğlu, Belirli Süreli İş Sözleşmesi (n 9) 134; Markus Sädevirta, A Comparative Study of the Regulation Governing the Use of Fixed-Term Contracts in Three EU Member States (1st edn, Unigrafia 2013) 13 vd; Alman hukuku için bkz Güzel, Özkaraca ve Ugan (n 9) 508 vd; Bozkurt Gümrükçüoğlu, Belirli Süreli I̦ş Sözleşmesi (n 9) 142 vd; Fransız Hukuku için bkz Güzel, Özkaraca ve Ugan (n 9) 491 vd; Sädevirta, (n 90) 253 vd.

91 Aynı maddeye göre ayrıca "Üye devletler bunu yaparken, belirli iş kollarının velveya işçi gruplarının ihtiyaçlarını dikkate almalıdırlar. Üye devletler ayrıca, sosyal taraflara danışarak belirli süreli iş sözleşmelerinin hangi koşullarda zincirleme olduğunu ve belirsiz süreli kabul edilebileceğini de belirleyebileceklerdir.” Çerçeve Antlaşma'ya ilişkin ayrıntılı açıklamalar için bkz Başterzi, 'Avrupa Birliği Konseyi’ (n 10) 182-183; Güzel, Özkaraca ve Ugan (n 9) 540-550; Bozkurt Gümrükçüoğlu, Belirli Süreli İ̧s Sözleşmesi (n 9) 135-136; Mustafa Uğur Aksoy, 'Alman Kısmi Süreli Çalışma ve Belirli Süreli İş Sözleşmeleri Hakkında Yasa ve Çevirisi’ (2014) 20(Özel Sayı) Marmara Üniversitesi Hukuk Fakültesi Hukuk Araștırmaları Dergisi (Prof. Dr. Ali Rıza Okur'a Armağan) 1215, 1218-1219; Sudabeh Kamanabrou, 'Successful Rules on Successive Fixed-Term Contracts?' (2017) 33 (2) International Journal of Comparative Labour Law and Industrial Relations 221, 223 vd; Avrupa Birliği üyesi ülkelerde belirli süreli iş sözleşmelerinin yenilenmesinde Çerçeve Sözleşmenin açıklanan hükmü dikkate alınmış olmakla birlikte hükmün seçenek sunması ülkeden ülkeye değişen düzenleme şekillerine sebep olmuştur. Bkz ibid 226, 229 vd. 
Görüleceği üzere, Türk kanun koyucu belirli süreli iş sözleşmesinin yenilenmesinde Çerçeve Antlaşma ile uyumlu olarak bir önlemi benimsemiştir. Ancak, bu önlem Çerçeve Antlaşmaya uyum için yegâne yöntem olmadığı gibi en etkin yöntem de değildir.

Dolayısıyla, İş Kanunu m. 11 hükmü, mehaz düzenlemelere uygun olmakla birlikte aşağıda detaylı olarak açıklanacağı üzere belirli süreli iş sözleşmesinin yapılması ve yenilenmesi bakımından uygulamada ortaya çıkan sorunları çözmekte yeterli olmamıştır. Biz de İş Kanunu m. 11 hükmü ile belirli süreli iş sözleşmesinin yapılması ve yenilenmesi için öngörülen esasları doktrin görüşleri ve yargı kararlarına da değinerek ayrı ayrı değerlendireceğiz ve uygulamadaki sorunların çözülmesine yönelik önerilerde bulunmaya çalışacağız.

\section{2. İş Kanunu Kapsamında Belirli Süreli İş Sözleşmesinin İlk Defa Yapılmasına İlişkin Esasların Değerlendirilmesi}

\section{a. Doktrindeki görüşler}

İş Kanunu m. 11/1 hükmü ile, belirli süreli iş sözleşmelerinin yapılmasında objektif neden aranması, işçiler bakımından önemli bir koruma sağlamakla birlikte belirli süreli iş sözleşmesinin uygulamasını son derece sınırlı kılmaktadır.

Bu düzenleme ile işçilerin korunmasına kıyasla işletmelerin esneklik ihtiyaçlarının yeterince gözetilmemiş olması doktrinde eleştirilmektedir ${ }^{92}$. Soyer, iş sözleşmesinin süreye bağlanmasını sadece hukuki bir sorun olarak görmemek gerektiğini belirtirken; belirli süreli iş sözleşmelerini istihdam yaratan bir sosyal politika aracı olduğunu vurgulamaktadir ${ }^{93}$.

\footnotetext{
2 Alpagut, '4857 Sayı1ı Yasa' (n 10) 73; Gülsevil Alpagut, ‘AB'nde Güvenceli Esneklik ve Türkiye'deki Yasal Düzenlemeler' (2008) 1 TİSK Akademi 6, 23-24; Soyer, '6098 Sayılı Türk Borçlar Kanunu’ (n 13) 12; Süzek (n 9) 240; Başterzi, 'Objektif Neden' (n 10) 432; G Burcu Yıldız, 'Güvenceli Esneklik ve 4857 Sayılı İş Kanunu', iç Süleyman Başterzi (ed) Prof. Dr. Sarper Süzek'e Armağan C. 1 (Beta 2011) 203, 209; Bozkurt Gümrükçüoğlu, Belirli Süreli İş Sözleşmesi (n 9) 170; Şahin Emir (n 33) 131, 148; İş Kanunu ve TBK kapsamındaki belirli süreli iş sözleşmeleri bakımından ilk defa sözleşmenin yapılmasında objektif nedenin aranmadığı yönünde azınlık görüşünün sahibi olan Taşkent ise maddelerin çağdaş anlayış ve gelişmelere uygun olduğunu ve "esneklik" içerdiğini ifade etmektedir. Yazar, aksine görüşün esnekliği ortadan kaldıran zorlama bir yorum olduğunu savunurken işçinin yararına sonuç doğurmayacağını, aksine istihdamın engellenmesi nedeniyle işçinin zarar göreceğini belirtmektedir, Taşkent (n 9) 29.

Mevcut düzenleme ile belirli süreli iş sözleşmesinin ilk defa yapılmasında objektif nedenin aranmasını isabetli bulan görüş için ise bkz Güzel ve Ertan, (n 29) 398; ayrıca Güzel, Özkaraca ve Ugan (n 9) 487-488. Güzel ve Ertan, yapılan araştırmaların sanılanın aksine belirli süreli iş sözleşmelerinin istihdam açısından beklenen faydayı sağlayamadığını ve dolayısıyla belirli süreli iş sözleşmesinin iş hukukunda esneklik iddiasıyla yaygınlaştırılması gereken görüşe ihtiyatla yaklaşılması gerektiğini savunmaktadırlar. Zira, yazarlarca belirli süreli iş sözleşmeleri, daha yüksek bir personel dalgalanmasına yol açmakta, işçilerin mesleki gelişimini engellemekte ve işçilerin daha düşük ücretlerle çalışması sonucunu doğurmaktadır. Bunların da bir taraftan uzun dönemde işverenin rekabet gücünü azaltmasına zemin hazırladığı; diğer taraftan ise işçinin sürekli işyeri ve iş değiştirmesinin kariyerini olumsuz şekilde etkilediği ifade edilmektedir. Bkz Güzel ve Ertan, (n 29) 398.

93 Yazar, belirli süreli iş sözleşmelerinin bu yönü dikkate alınarak düzenlendiğinde ise sözleşme süresi hakkında en çok iki yıl gibi bir azami süre konması gerektiğini savunmaktadır. Soyer, ‘6098 Sayılı Türk Borçlar Kanunu’ (n 13) 12.
} 
Benzer bir yaklaşımla, istihdamı teşvik amacıyla kanun değişikliği ile objektif neden koşulu bakımından bazı istisnalar getirilmesini öneren yazarlar da mevcuttur ${ }^{94}$.

Alpagut, küreselleşme ile birlikte belirli süreli iş sözleşmesinin sınırlandırılması yönündeki eğilimin yön değiştirdiği; istihdamın artırılması ve işsizlere belirli süreli de olsa çalışma imkânı sağlanması amacıyla bu tür sözleşmelerin kurulması imkânının Avrupa Birliği'nin ve üye ülkelerin gündeminde olduğuna işaret etmiştir ${ }^{95}$. İş Kanunu m. 11/1 hükmünün esneklik düşüncesiyle bağdaşmadığını savunan yazar, maddenin bilim kurulu taslağındaki hâlinde ise Avrupa hukukundaki eğilime uygun bir şekilde belirli süreli iş sözleşmesinin ilk kez yapılmasında objektif neden koşuluna yer verilmemiş olduğuna işaret etmiş; Meclis’te verilen önerge sonucu madde metninin bugünkü hâline getirilmesini eleştirmiştir ${ }^{96}$. Yazar, bu bakış açısıyla kanun hükmünün değiştirilmesi ve ilk defa çalışma yaşamına giren işçiler, Türkiye İş Kurumu'nda işsiz olarak kayıtlı olan kişiler, yeni faaliyete başlayan işverenler ya da faaliyet alanını genişleten işverenlerle ilk kez yapılacak belirli süreli iş sözleşmelerinde objektif neden koşuluna istisna getirilmesi gerektiğini ileri sürmüştür ${ }^{97}$.

İş Kanunu m. 11/1 hükmünü katı olması nedeniyle eleştiren bir diğer yazar Caniklioğlu, söz konusu maddenin tekrar düzenlenmesi gerektiğini savunmaktadır. Yazar, belirli süreli iş sözleşmelerinin ilk defa yapılmasında objektif nedenin aranmaması gerektiğini; bu sayede ülkemizdeki genç işsizliğin belirli bir ölçüde engellenmesinin sağlanabileceğini ifade ederken TBK ile de uyum sağlanmış olacağına dikkat çekmektedir. Ancak yazar bu biçimde yapılabilecek belirli süreli iş sözleşmelerine üst sınır getirilmesinin de şart olduğunu vurgulamaktadır. Yazar ayrıca, yeni kurulan işyerleri bakımından da objektif neden koşuluna bir istisna öngörülebileceğini de belirtmektedir ${ }^{98}$.

Bozkurt Gümrükçüoğlu da belirli süreli iş sözleşmesinin ilk defa yapılması bakımından daha esnek bir düzenlemenin getirilmesi gerekliliğini vurgulamakla birlikte, getirilecek düzenlemenin kötüye kullanılması olasılığına da işaret etmektedir. $\mathrm{Bu}$ çerçevede yazar, Alman Hukuku'ndan hareketle, belirli bir yaşın üzerinde olan ve belirli bir süreden beri işsiz olan işçilerle belirli süreli iş sözleşmesi yapma imkânı getirilmesini önerirken yapılacak kanuni değişikliğin yaş ayırımcılığına yol açmaması gerektiğinin de altını çizmektedir. Bu bakımdan da emeklilik yaşına yakın ve işsiz işçiler bakımından belirli süreli iş sözleşmesinin yapılmasında objektif neden

\footnotetext{
94 Alpagut, ‘4857 Sayı1ı Yasa' (n 10) 78; Nurşen Caniklioğlu, ‘'̇ş Kanununun 10. Y1lında Belirli Süreli İş Sözleşmesi ile Kısmi Süreli İş Sözleşmesi ve Uygulamada Yaşanan Sorunlar’ (2016) 10. Yılında 4857 Sayılı İş Kanunu (Uygulama Sorunları ve Çözüm Önerileri) Sempozyumu, Ankara Yıldırım Beyazıt Üniversitesi Hukuk Fakültesi-Çelik İş Sendikası, 168; Alpagut, 'Güvenceli Esneklik' (n 92) 22-24; Süzek (n 9) 240; Yıldız (n 92) 211; Bozkurt Gümrükçüoğlu, Belirli Süreli İ̧̧ Sözleşmesi (n 9) 170; Şahin Emir (n 33) 131, 148.

95 Alpagut, 'Güvenceli Esneklik' (n 92) 22.

96 ibid 23-24.

97 ibid 22; Alpagut, ‘4857 Say1lı Yasa' (n 10) 78.

98 Caniklioğlu, 'İș Kanununun 10. Yılı' (n 94) 168.
} 
aranmamasının yerinde olacağını ifade etmiştir. Yazar ayrıca, yeni kurulan işletmeler bakımından belirli bir süreyle sınırlı olarak objektif neden aranmaksızın belirli süreli iş sözleşmesi yapılması imkânı yönünde kanun değişikliğini de önermektedir ${ }^{99}$.

Şahin Emir de, kanunda değişiklik yapılarak Alman hukukunda olduğu gibi belirli yaşın üzerinde olan ve belirli bir süre işsiz olan kişilerle ilk defa yapılacak olan belirli süreli iş sözleşmelerinde objektif neden koşulunun aranmayabileceğini savunmuştur. Yazar ayrıca ilk defa iş hayatına giren işçiler, yeni faaliyete başlayan işverenler ya da emekliliğine kısa bir süre kalan kişilerle objektif koşullara bağlı olmadan belirli süreli iş sözleşmesi yapılmasına imkân tanınabileceğini ileri sürmüştür ${ }^{100}$.

\section{b. Torba Kanun Teklifi'nin değerlendirilmesi}

Doktrinde savunulan İş Kanunu m. 11/1 hükmü ile belirli süreli iş sözleşmesinin yapılmasında objektif neden koşuluna yönelik yukarıda izah edilen görüşler, yasama organı tarafından da dikkate alınmıştır. Belirli yaş grubundaki işçiler ile belirli süreli iş sözleşmelerinin yapılmasını (ve de yenilenmesini) objektif neden koşulundan bağışık tutan bir kanun teklifi, 5 Kasım 2020 tarihi itibariyle TBMM'nin gündemine taşınmıştır ancak kanunlaşmamıştır.

Söz konusu teklif, TBMM'ye gönderildiği hâlinde, İş Kanunu'nun 11. maddesine fikra ilave etmekte idi. Madde gerekçesinde 25 yaşını doldurmayan veya 50 ve üzeri yaşta olan işçilerin istihdam piyasasına girişlerinin daha kolay hâle getirilmesi amacını taşıdığ1 ifade edilen ${ }^{101}$ fikraya göre, "Belirli süreli iş sözleşmesi, işçinin yirmibeş yaşını doldurmamış veya elli ve daha yukarı yaşta olma koşulunu sağlaması kaydıyla birinci ve ikinci fikradaki koşullar aranmadan yazılı şekilde yapılabilir. Yirmibeş yaşını doldurmamış işçiler ile yapılacak belirli süreli iş sözleşmelerinin süresi işçinin yirmi beş yaşını doldurduğu tarihi geçmez. Bu fikra uyarınca bir defada veya yenilenerek yapılan belirli süreli iş sözleşmelerinin toplam süresi iki yılı geçemez.".

Belirtelim ki, Torba Kanun Teklifi ile benzer esasları benimseyen bir düzenleme, Alman Kısmi Süreli ve Belirli Süreli İş Sözleşmeleri Hakkında Kanunu'nda yer almakta idi. Kanun'un $\S 14$ hükmünde, belirli süreli iş sözleşmesinin ilk defa yapılmasında objektif neden koşuluna yer verilirken maddenin 3. fikrası ile "52 yaşından büyük olan işçiler" istisna tutulmuştu; yani "52 yaşından büyük olan

99 Bozkurt Gümrükçüoğlu, Belirli Süreli İş Sözleşmesi (n 9) 170.

100 Şahin Emir (n 33) 131, 148.

101 Madde gerekçesine göre; "Belirli süreli işlerde veya belli bir işin tamamlanması veya belirli bir olgunun ortaya çıkması gibi objektif koşullara bağlı olarak işveren ile işçi arasında yazıl ş̧ekilde yapılan iş sözleşmeleri belirli süreli iş sözleşmesi olarak tanımlamakta ve belirli süreli iș sözlesmesi esaslı bir neden olmadıkça, birden fazla üst üste (zincirleme) yapılamamaktadır.

${ }^{M a}$ dde ile yirmibeş yaşını doldurmayan veya elli ve üzeri yaşta olan iş̧̧ilerle yapılacak belirli süreli iş sözleşmelerinin şartları yeniden düzenlenerek mevcut sınırlamalara tabi olmaksızın belirli iş sözleşmesi yapılabilmesi, işçinin aynı işverenin işyerinde belirli süreli iş sözleşmesi ile çalıştırllabileceği azami süre sınırı belirlenmesi ve bu kapsama girenlerin istihdam piyasasına girişlerinin daha kolay hâle getirilmesi amaçlanmaktadır." 
işçiler” ile objektif neden olmaksızın belirli süreli iş sözleşmesi yapılmasına imkân verilmişti.

Alman Kısmi Süreli ve Belirli Süreli İş Sözleşmeleri Hakkında Kanunu § 14/3 hükmü, ön karar usulü ile Avrupa Birliği Adalet Divanı tarafından incelenmiştir. Divan tarafından Mangold karar1 ${ }^{102}$ ile kanun hükmünün İş ve Meslekte Eşit İşlem Direktifi'nde ${ }^{103}$ yasaklanan yaş ayırımcılığı yasağına aykırı olduğu tespit edilmiştir.

Mangold kararında inceleme konusu olan söz konusu kanun hükmü uyarınca, 52 yaşından büyük işçiler ile belirli süreli iş sözleşmesi yapılması daha kolay olacak ve bunun sonucunda da 52 yaşından büyük işçiler, daha genç işçilere nazaran az korumaya tabi olacaklardır. Dolayısıyla bu hükmün uygulanması ile, 52 yaşından büyük işçiler aleyhine yaş temelinde davranış farklılı̆̆ı ortaya çıkmaktadır. Ancak Divan'ın da değindiği üzere bu durum, otomatikman yaş ayırımcılığı yasağının ihlali olarak değerlendirilmemiştir. Zira, yaş temelinde davranış farklılıklarının haklı kılınması hukuken mümkündür. Nitekim İş ve Meslekte Eşit İşlem Direktifi de istihdamda yaş ayırımcılığını yasaklarken bu yasağı mutlak olarak düzenlememiş ve yaş temelinde davranış farklılıklarının haklı kılınmasına ilişkin ayrı bir maddeye yer vermiştir. Direktif'in 6. maddesine göre, üye devletler ulusal hukuklarında, özellikle istihdam politikaları, iş piyasası ve mesleki eğitimi kapsayan meşru bir amaca ulaşmak için yaşa dayalı farklı uygulama yapılmasının ayırımcılık yaratmayacağına dair düzenleme yapabilirler. Ancak bunun için meşru amaca ulaşmak için kullanılan araçların uygun ve gerekli olması; yani ölçülülük ilkesine uygun olması gerekmektedir ${ }^{104}$.

Dolayısıyla, Divan Alman Kısmi Süreli ve Belirli Süreli İş Sözleşmeleri Hakkında Kanun $\S 14 / 3$ hükmünün yaş ayırımcılığg oluşturup oluşturmadığının tespitinde, yaş temelinde davranış farklılıklarına imkân veren bu kanun hükmünün amacının "meşru bir amaç" olup olmadığı ile incelemesine başlamıştır. Divan’a göre, 52 yaşından büyük olan işçi grubunun belirli süreli iş sözleşmeleri için öngörülen korumadan istisna kılınması ile amaçlanan "işsiz yaşlı isçilerin iş piyasasına entegrasyonu", meşru bir amaçtır.

Direktif' in 6. maddesine göre yaş temelinde davranış farklılıklarına sebep olan bu hükmün yaş ayırımcılığı oluşturmaması için amacın meşru olması tek başına yeterli olmayıp bunun yanında kanun hükmünün (aracın) bu amacı sağlamak için ölçülü olması gerekmektedir. Divan da incelemesine ölçülülük testi ile devam etmiştir. Bunun için de öncelikle "uygunluk" testi yapmıştır; söz konusu kanun hükmünün

\footnotetext{
102 C-144/04 Mangold v. Rüdiger Helm [2005] ABAD I-09981.

$10327 \mathrm{Kasim} 2000$ tarihli ve 2000/78/EC sayll Direktif, https://eur-lex.europa.eu/legal-content/EN/TXT/?uri=celex\%3A32000L0078 (Erişim tarihi: 13.01.2021).

104 Direktif uyarınca yaş temelinde davranış farklılıkların haklı kılınmasına ve bu bağlamda Divan tarafından uygulanan ölçülülük testine ilişkin detaylı açıklamalar için bkz Canan Ünal, Işs Hukukunda Yaş̧ Ayırımcılı̆̆ı (1. Bası, On İki Levha 2018) 196 vd; Divan'ın genel olarak ölçülülük testine ilişkin detaylı açıklamalar için bkz Deniz Ugan Çatalkaya, $\dot{I}_{S ̧}$ Hukukunda Ölçülülük İlkesi (1. Bası, Beta 2019) 94 vd.
} 
(aracın) 52 yaşın üstündeki işçilerin işlerini kaybetmesini de kolaylaştıracak nitelikte olması dolayısıyla yaşlı işçilerin iş piyasasına entegrasyonu amacını sağlamakta uygun bir araç olmadığını tespit etmiştir. Yani kanun hükmü, "uygunluk" testini geçememiştir.

Divan ardından, "gereklilik” testi ile devam etmiş; ancak kanun hükmünün (aracin) amacı sağlamakta gerekli de olmadığı sonucuna ulaşarak bu testi de geçemediğini tespit etmiştir. Zira, Divan'ın belirttiği üzere, 52 yaşından büyük olan işçi grubunun belirli süreli iş sözleşmeleri için öngörülen korumadan istisna kılınması, en az ayırımcı yol değildir; dolayısıyla amacı sağlamak için gerekli olmayıp bu araç ile gerekli olanın ötesine geçilmiştir. Tüm bu değerlendirmelerin sonucu, Alman Kısmi Süreli ve Belirli Süreli İş Sözleşmeleri Hakkında Kanun § 14/III hükmü meşru bir amaca dayansa da hükmün bu amacı sağlamaya uygun ve gerekli olmadığını tespit eden Divan, hükmün yaş ayırımcılığı yasağına aykırı olduğu sonucuna ulaşmıştır ${ }^{105}$.

Avrupa'da yaş ayırımcılığının keşfedilmesi ve ele alınmasında önemli bir yere sahip olan ${ }^{106}$ Mangold kararının ardından Alman kanun koyucu yaş ayırımcılı̆̆ı yasağına aykırı kanun hükmünü, Yaşlıların İstihdam Edilme Olanaklarının İyileştirilmesi Hakkında Yasa ile 01.05.2007 tarihinden itibaren geçerli olmak üzere değiştirmiştir ${ }^{107}$. Yeni düzenleme 52 yaşını doldurmuş kişiler ile objektif neden olmaksızın belirli süreli iş sözleşmesi yapılabilmesi için birtakım ek şartlar aranmıştır. Buna göre yeni düzenleme ile 52 yaşını doldurmuş kişilerin iş sözleşmesinin başlangıç tarihinden önce en az 4 ay süreyle Sosyal Güvenlik Kanunu uyarınca işsiz sayılıp transfer kısa çalışma ödeneği almış olması veya kamu tarafından finanse edilen bir istihdam tedbirinde yer almış olması aranmaktadır. Öte yandan bu koşulların varlığı hâlinde de objektif neden olmaksızın 52 yaşını doldurmuş kişilerle sınırsız olarak değil, en fazla 5 yıl süre ile belirli süreli iş sözleşmesi yapılabilmesine imkân verilmiştir ${ }^{108}$.

Mangold kararı ve kararın Alman mevzuatına tesiri bizim açımızdan da yol gösterici niteliktedir. Yaş ayırımcılığ 1 yasağının uluslararası hukuktan kaynaklanan temel ilke ve temel hak olmasi ${ }^{109}$, hukukumuz bakımından da Avrupa Birliği üyesi ülkeler ile benzer esaslara tabi olması sonucunu doğurmuştur ${ }^{110}$. Ayrıca önemine uygun olarak

105 C-144/04 Mangold v. Rüdiger Helm [2005] ABAD I-09981, para. 65; açıklamalar için bkz Ünal (n 104) 240-241.

106 Sebastian Krebber, 'The Social Rights Approach of the European Court of Justice to Enforce European Employment Law' (2006) 27 (3) Comparative Labor Law \& Policy Journal, 377, 402; Ünal (n 104) 2.

107 Alman kanun koyucu ayrıca Birlik hukukunun ve özellikle Mangold kararının etkisiyle 2006 yılında Genel Eşit İşlem Kanunu'nu (Allgemeine Gleichbehandlungsgesetz) yürürlüğe koymuştur.

108 Kanun hükmü için bkz https://www.gesetze-im-internet.de/tzbfg/_14.html (Erişim tarihi: 07.11.2020); ayrıca bkz Güzel, Özkaraca ve Ugan (n 9) 514.

109 Bkz Kübra Doğan Yenisey, 'İşverenin Sözleşmenin Feshinde Eşit Davranma Borcuna İlişkin İki Yargıtay Kararının Düşündürdükleri'(2006) 2 Sicil Dergisi 60, 61; Ünal (n 104) 59, benzer yönde, Sibel İnceoğlu, 'Türk Anayasa Mahkemesi ve İnsan Hakları Avrupa Mahkemesi Kararlarında Eşitlik ve Ayrımcılık Yasağı' (2006) 11 (4) Çalışma ve Toplum Dergisi 45, 48; C-43/75 Gabrielle Defrenne v. Sabena II [1976] ABAD 00455, para. 12; Krebber, (n 106) 398.

110 Yaş ayırımcılığı yasağının temel hak niteliğinin sonuçları için bkz Ünal (n 104) 147 vd. 
hukukumuzda anayasal bir buyruk ile de yasaklanan yaş ayırımcılığına ${ }^{111}$ ilişkin sinırlamalar ancak kanunla ve ölçülülük ilkesine uygun olarak yapılabilecektir. Nitekim Anayasa m. 13 hükmü ile, temel hak ve özgürlüklerin ancak kanunla sınırlandırılabileceği ve bu sınırlamaların ölçülülük ilkesine aykırı olamayacağı düzenlenmiştir. Bu anayasal buyruğun muhatabı olan yasama organı, kanun yaparken ölçülülük ilkesine riayet etmek zorundadır ${ }^{112}$. Dolayısıyla, hukukumuzda da kanun hükümlerinin yaş ayırımcılığı yasağına aykırı olmaması ve ölçülülük ilkesine uygun olması gereği, kanun yapımında, Birlik Hukuku ile benzer esasların dikkate alınmasını gerekli kılmaktadır ${ }^{113}$.

Bu açıklamaların 1şı̆̆ında; Torba Kanun Teklifi'nde İş Kanunu m. 11 hükmüne ilave öngören fikra incelendiğinde ise, bu düzenlemenin kanunlaşmamasının isabetli olduğu sonucuna ulaşılmaktadır. Zira, madde gerekçesinde yer alan amaç, 25 yaşını doldurmayan veya 50 ve üzeri yaşta olan işçilerin istihdam piyasasına girişlerinin daha kolay hâle getirilmesi olup bu amaç, meşru olarak değerlendirilebilecek olsa da söz konusu fikra hükmü, bu amacı sağlamak için ölçülü değildir. Aksine, bu düzenleme 25 yaşını doldurmayan ve/veya 50 ve üzeri yaştaki işçilerin istihdam piyasasına girişlerini kolaylaştırmasının yanında işlerini kaybetmelerini yani istihdam piyasasından çıkışlarını da kolaylaştıracaktır. Dolayısıyla Torba Kanun Teklifi'ndeki düzenleme, gerekçede belirtilen amacı sağlamaya uygun bir araç değildir. Yine bu düzenleme, 25 yaşını doldurmayan ve/veya 50 ve üzeri yaştaki işçilerin istihdam piyasasına girişlerini kolaylaştırma amacını sağlamak için gerekli de değildir. Zira, bu amacı sağlamak için daha az ayırımcı yollar mevcuttur. Oysa söz konusu düzenleme kanunlaşsa idi gerekli olanın ötesine geçilmiş olacaktı.

\section{c. Görüşümüz ve Önerilerimiz}

İş Kanunu m. 11/1 hükmü ile, belirli süreli iş sözleşmelerinin yapılmasında objektif neden aranması, işçiler bakımından önemli bir koruma sağlamakla birlikte uluslararası rekabet ve piyasa koşullarına karşı esneklik ihtiyacı olan işletmeler aleyhine bir dengesizlik yaratmaktadır. Dolayısıyla, kanunda bir değişiklik yapılması gerektiği yönündeki görüşü biz de paylaşmaktayız.

Ancak açıktır ki, yapılacak kanun değişikliğinin de yeni hukuki sorunları beraberinde getirmemesi gerekmektedir. Yasama organı, öncelikle işçinin korunması ihtiyacı ile işletmeler bakımından esnekleşme ihtiyacı arasındaki hassas dengeyi

\footnotetext{
111 Anayasa m. 10/1 hükmüne göre "Herkes, dil, trk, renk, cinsiyet, siyasi düşünce, felsefi inanç, din, mezhep ve benzeri sebeplerle ayırım gözetmeksizin kanun önünde eşittir.". Bu fikrada "ve benzeri" ifadesine yer verilerek örnekseme yoluyla sayılan ayırımcılık temellerinden biri de "yaş"tır. Detaylı açıklamalar için bkz ibid 40-41 ve dn. 145, 88 vd.

112 Ölçülülük ilkesinin yasama organını yönlendirici bir işlevi olduğu yönünde, Yüksel Metin, Ölçülülük İlkesi, Karşılaştırmal Bir Anayasa Hukuku Incelemesi (1. Bası, Seçkin 2002) 249; ölçülülük ilkesinin temel hak ve özgürlüklerin pratik uyuşumunun sağlanması işlevi için bkz Ugan Çatalkaya (n 104) 36-40.

113 Benzer yönde değerlendirmeler için bkz Güzel ve Ertan, (n 29) 415.
} 
gözetmelidir. Ayrıca bunun yanında, Torba Kanun Teklifi'ndeki gibi yaş ayırımcıllğg1 yasağına aykırılık oluşturacak değişiklikler de yapılmamalıdır.

Bu bağlamda, İş Kanunu m. 11 hükmünde yer alan belirli süreli iş sözleşmesinin ilk defa yapılmasında objektif neden koşuluna istisnalar öngörülebilir. Ancak, yapılacak kanuni değişiklik ile, yaş ayırımcılığı yasağı dikkate alınarak, salt yaş grupları bakımından bir istisna getirilmemelidir. Bunun yerine belirli bir yaşın üstünde olan işçiler ile ancak bir süredir işsiz olmaları hâlinde belirli süreli iş sözleşmesinin yapılmasında, objektif neden aranmaması düşünülebilir. Zira, bu yönde bir düzenleme, zaten işsiz olan kişilerin istihdam piyasasına girişlerini kolaylaştırma amacı sağlamak için "uygun" ve "gerekli"; yani "ölçülü" olabilecektir. Dolayısıyla, bu yönde bir kanun hükmü, yaş ayırımcıllğı yasağına aykırılık da oluşturmayabilecektir ${ }^{114}$.

Dikkat çekelim ki, belirli süreli iş sözleşmesinin yapılmasına ilişkin objektif neden koşulundan belirli bir yaşın altında olan işçilerin istisna tutulması, belirli bir süre işsiz olma koşuluna bağlansa da yaş ayırımcılığı oluşturur. Gerçekten, bu yönde bir düzenleme ile 25 yaşı doldurmamış bu kişilerin istihdam piyasasına girişleri kolaylaşabilecek olsa da genç işsizliği ile mücadele için daha az ayırımcı yöntemler mevcuttur.

Aksinin kabulünde ise gençler, belirsiz süreli iş sözleşmesi ile çalışmaları hâlinde sağlanan korumadan mahrum kalacaklar ve genç işçiler ile işletmeler arasındaki denge işçiler aleyhine telafisi güç şekilde bozulacaktır. Bu durumda işletmelerin 25 yaşından küçükler ile kuracakları belirli süreli iş sözleşmesinin, adeta deneme süreli iş sözleşmelerine dönüşmesi olasıdır. İş ilişkisinin devamında olmasa da sözleşme süresinin sonunda tazminatsız ve bildirimsiz olarak sözleşmeler sona erecektir. Dolayısıyla belirli süreli iş sözleşmesinin yapılmasına ilişkin objektif neden koşulundan belirli bir yaşın altında olan işçilerin istisna tutulması ilave olarak işsiz olmaları koşuluyla da yaş ayırımcılığı yasağına aykırılık oluşturacaktır.

Ayrıca bu durum 25 yaşından küçük işçilerin kıdemleri ne kadar artarsa artsın iş güvencesinin kapsamına da girememeleri sonucunu doğuracaktır. Oysa İş Kanunu m. 11 hükmünün mehaz düzenlemelerinden biri olan 158 sayılı ILO Sözleşmesi ile taraf ülkelere işverenlerin iş güvencesi hükümlerinin dışında bırakmak amacıyla belirli süreli iş sözleşmesi yapma hakkını kötüye kullanmalarını önleyici gerekli tedbirlerin alınması yükümlülüguünü yüklemiştir. 25 yaşından küçük işçileri iş güvencesi kapsamından dışlayıcı bu düzenleme, söz edilen ILO sözleşmesine aykırılık oluşturacaktır.

114 Alman hukukunda Divan'ın Mangold kararından sonra benzer yönde görüş için bkz Wolfgang Däubler, und Martin Bertzbach (Hrsg), Allgemeines Gleichbehandlungsgesetz: Handkommentar (Nomos 2013) §10, Rn. 31. 


\section{3. İş Kanunu Kapsamında Belirli Süreli İş Sözleşmesinin Yenilenmesi İlişkin Esasların Değerlendirilmesi}

\section{a. Doktrindeki görüşler ve Yargıtay kararları}

İş Kanunu'nun m. 11 hükmünün 2. ve 3. fikraları ile belirli süreli iş sözleşmelerinin objektif neden olmadıkça birden fazla üst üste yapılamayacağı düzenlenmekle birlikte objektif nedenin bulunması hâlinde sözleşmenin kaç defa yenilenebileceği veya sözleşmenin toplam süresine ilişkin bir sınırlama bulunmamaktadır. Kanun hükmü bu yönüyle uygulamada belirsizliklere de sebep olduğu için doktrin tarafindan eleştirilmektedir ${ }^{115}$.

Alpagut bu madde uyarınca işverenin işletmenin iş gücü ihtiyacını devamlı olarak belirli süreli iş sözleşmeleri ile karşılama ihtimaline dikkat çekerken belirli süreli iş sözleşmesinin yenilenmesine ilişkin sınırlama getirilmesi gerektiğini ileri sürmektedir ${ }^{116}$.

Güzel, Özkaraca ve Ugan da objektif nedenin bulunması hâlinde belirli süreli iş sözleşmelerinin sınırsız olarak yenilenebileceğine işaret etmekte ve bu durumun hukukumuzda belirli süreli iş sözleşmelerinin yenilenmesi bakımından belirsizlik yarattığını ileri sürmektedirler ${ }^{117}$. Yazarlar bu belirsizliği ortadan kaldırmak için, kanunda değişiklik yapılmasını ve objektif neden bulunsa dahi belirli süreli iş sözleşmelerinin en fazla üç yll gibi azami bir süre için sınırlandırılmasını önermektedirler ${ }^{118}$.

Başterzi de kanun değişikliği ile azami süre ve sayı sınırı öngörülmesi gerektiğini savunmakla birlikte mevcut düzenleme uygulanırken de objektif nedenin varlığı devam ettiği sürece sınırsız sayıda belirli süreli iş sözleşmesi yapılamayacağını belirtmektedir. Yazar, aksinin kabulünün kanunun amacına ve dürüstlük kuralına aykırılık teşkil edeceğini ifade etmektedir ${ }^{119}$.

Bozkurt Gümrükçüoğlu, kanun ile belirli süreli iş sözleşmelerinin yenilenmesinde bir sınır getirilmemesinin uygulamada sıkıntı doğurabileceğini belirtmekle birlikte, süre ve sayı sınırlaması getirilmesinin de gerçekten belirli süreli iş sözleşmesi yapılması ihtiyacının olduğu durumlarda sorun oluşturabileceğine dikkat çekmektedir.

\footnotetext{
115 Alpagut, '4857 Sayılı Yasa' (n 10) 86; Ali Güzel, 'Bireysel İş İlişkisinin Kurulması, Hükümleri ve İşin Düzenlenmesi' (2007) Yargıtay'ın İș Hukuku ve Sosyal Güvenlik Hukuku Kararlarının Değerlendirilmesi 2005, 11, 32; Süzek (n 9) 250; Başterzi, 'İş İlişkisinin Kurulması' (n 30) 73; Güzel, Özkaraca ve Ugan (n 9) 558; Bozkurt Gümrükçüoğlu, Belirli Süreli Işs Sözleşmesi (n 9) 175; ayrıca bkz Yıldız (n 92) 211; aksi yönde, Güler (n 10) 51. Güler, belirli süreli iş sözleşmesinin sayı bakımından sınırlandırılmamasının bir sorun oluşturmadığını savunmakta ve sözleşmenin devamlı olarak yenilenmesinde hakkın kötüye kullanılmasına dayanılamayacak olsa da yenilenmenin sürekli olarak aynı nedene dayanması veya nedenin devamlılık arz etmesi gibi durumlarda artık objektif nedenin varlığından bahsedilemeyeceğini ifade etmektedir.

116 Alpagut, ‘4857 Sayılı Yasa' (n 10) 86.

117 Güzel, Özkaraca ve Ugan (n 9) 559-560.

118 Güzel, Özkaraca ve Ugan (n 9) 560, 562

119 Başterzi, 'İş İlişskisinin Kurulması' (n 30) 73.
} 
Yazar yine de süre bakımından sınır getirilmesi hâlinde görüşünü ortaya koymuştur. Yazara göre, bu sürenin belirlenmesinde, TBK m. 430/3 hükmünde yer alan ve belirli süreli iş sözleşmesinin işçi tarafından süreli fesih yoluyla sona erdirilebileceğinin kabul edildiği sınır olan 10 yıl esas alınabilir. Ancak yazar, 10 yılın uzun olduğunu da belirterek TBK m. 430/3 hükmünde yer alan bu sürenin Alman Hukukunda olduğu gibi 5 yıla düşürülebileceği veya İş Kanunu'nda yapılacak bu yönde özel bir düzenleme ile 5 y1llık süre öngörülebileceğini ileri sürmektedir. Böylece belirli süreli iş sözleşmelerinin yenilenmesi de 5 yıllık azami süreye bağlanabilecektir ${ }^{120}$.

Belirtelim ki, Yargıtay da çeşitli kararlarında kanun ile belirli süreli iş sözleşmesi için azami süre sınırı öngörülmesini önermiş ve bu şekilde uygulamanın rahatlayacağını belirtmiştir ${ }^{121}$. Hatta 2005 yılında verdiği bir kararda, Yüksek Mahkeme, üst üste yapılan belirli süreli iş sözleşmeleri bakımından süre sınırı uygulamıştır. Söz konusu kararda, İş Hukukunda esas olanın belirsiz süreli iş sözleşmesi olduğu ve dosya içerisinde belirtilen objektif nedenlerin davacının yaptığı işle uyum göstermediği belirtildikten sonra şu açıklamalara yer verilmiştir: "Özel Kanunlar haricinde altı yıl gibi bir süre de ardarda yapılan belirli süreli iş sözleşmeleri 4857 sayılı Kanunun 11. maddesi amacı dışına çıkacağından işçinin belirsiz süreli iş sözleşmesinin çalıştı̆̆ kabul edilmelidir." 122 . Karar doktrinde isabetli bulunsa ${ }^{123}$ da belirli süreli iş sözleşmelerinin yenilenmesinde 6 yıllık sürenin her uyuşmazlıkta azami süre olarak değerlendirilmemesi gerektiğine de dikkat çekilmektedir ${ }^{124}$.

Görüldüğü üzere, Yargıtay da kararlarında belirli süreli iş sözleşmelerinin üst üste yenilenmek suretiyle amacına aykırı olarak uzun süre devam etmesinin ve kötüye kullanılmasının önüne geçme çabasındadır ${ }^{125}$. Bununla birlikte hem yargının hem doktrinin ortak görüşünün konunun yasama organı tarafından çözülmesi gerektiği yönünde olduğu anlaşılmaktadır.

\section{b. Torba Kanun Teklifi'nin değerlendirilmesi}

Torba Kanun Teklifi, belirli süreli iş sözleşmesinin yapılması yanında yenilenmesinde de objektif neden koşuluna yaş ile bağlantılı istisnalar getirmekte idi. Yukarıda belirli süreli iş sözleşmesinin ilk defa yapılmasında Teklif hükmüne ilişkin eleştirilerimiz ${ }^{126}$

\footnotetext{
120 Ayrıca yazar, uygulamadaki sorunlar için başka bir çözüm önerisinde de bulunmaktadır. Yazara göre, belirli süreli iş sözleşmesinin yenilenmesine esas teşkil eden objektif nedenin belirlenmesinde, süre ve sayı arttıkça başlangıçta kabul edilen objektif nedene göre daha güçlü bir neden aranmalıdır. Bozkurt Gümrükçüoğlu, Belirli Süreli İş Sözleşmesi (n 9) 170, 176-177.

121 Örnek kararlar için bkz Yargıtay 22 HD, 21722/25696, 25.09.2014; Yargıtay 9 HD, 32823/33161, 22.09.2011; Yargıtay 9 HD, 3392/23, 24.01.2011; Yargitay 9 HD, 20382/20662, 28.06.2010; Yargitay 9 HD, 942211563, 21.04.2009.

122 Yargitay 9 HD, 12170/15792, 05.05.2005.

123 Güzel, 'Bireysel İş İlişkisi' (n 115) 31-33; Güzel, Özkaraca ve Ugan (n 9) 559; ayrıca Bozkurt Gümrükçüoğlu, Belirli Süreli Iș Sözleşmesi (n 9) 176.

124 Bozkurt Gümrükçüoğlu, Belirli Süreli İş Sözleşmesi (n 9) 176.

125 Güzel, Özkaraca ve Ugan (n 9) 562.

126 Bkz yukarıda IV, 2, b.
} 
sözleşmenin yenilenmesi için de geçerlidir. Bu yönde bir düzenleme de yaş ayırımcılığg yasağına aykırılık teşkil edecektir.

\section{c. Görüşümüz ve Önerilerimiz}

Belirli süreli iş sözleşmesinin yenilenmesinde objektif neden koşulunu arayan İş Kanunu m. 11/2 hükmü, süre ve sayı sınırlaması içermediği için eleştirilmiştir. Ancak bu düzenlemenin dayanağı olan Çerçeve Antlaşma ile uyumsuz olduğu sonucuna ulaşılmamalıdır ${ }^{127}$. Aksine, yukarıda da izah edildiği üzere ${ }^{128}$, Çerçeve Antlaşma m. 5 hükmü esnek bir madde olup üye ülkelere, belirli süreli iş sözleşmesinin yenilenmesi bakımından seçenek önlemler sunmaktadır. Üye ülkeler, objektif neden koşulu, süre sinırlaması ve sayı sınırlamasından birini, ikisini ya da tamamını iktibas edebilir. Dolayısıyla, uyum için sunulan seçenek önlemlerden biri olan objektif neden koşuluna yer veren İş Kanunu m. 11 hükmü, Çerçeve Antlaşma ile uyumludur.

Öte yandan belirli süreli iş sözleşmesinin yenilenmesinde ulusal hukukta benimsenen seçenekler arttıkça işçilerin çok daha iyi bir korumaya sahip olduğu da düşünülmemelidir. Nitekim, Avrupa Birliği üyesi ülkelerin mevzuatlarına ilişkin yapılan karşılaştırmalı bir çalışmada, öngörülen sistemler arasında ciddi farklılıklar beklenmesine rağmen çoğu ülkenin Çerçeve Antlaşmaya uyumda başarılı olduğu tespit edilmiştir ${ }^{129,130}$.

Gerçekten bu çalışma ile, belirli süreli iş sözleşmesinin yenilenmesinde, hukukumuzda olduğu gibi sadece objektif neden koşuluna yer veren ülkeler olan Avusturya, Finlandiya ve Danimarka ${ }^{131}$ ile iki koşulun benimsendiği ülke mevzuatları arasında uyum anlamında ciddi bir farklılık olmadığı tespit edilmiştir. İki koşulu benimseyen ülkelerin farklı tercihleri de bu sonucu değiştirmemiştir. Örneğin; Fransa ve Lüksemburg hukuku, objektif neden ve azami sayı sınırlamas1 ${ }^{132}$; İspanya hukuku, objektif neden ve azami süre sınırlamas ${ }^{133}$; Hollanda ve İtalya hukuku ise, azami süre ve azami sayı sınırlaması öngörmektedir ${ }^{134}$. Ancak, bu ülkelerin ne birbirlerinden ne de diğer ülke mevzuatlarından uyum anlamında ciddi bir farklılıkları bulunmaktadır.

\footnotetext{
127 Benzer yönde, Başterzi, ‘İş İlişkisinin Kurulması’ (n 30) 71.

128 Bkz yukarıda IV, 1.

129 Yazara göre, belirli süreli iş sözleşmesinin yenilenerek kötüye kullanılmasını önleme seviyesi genel itibariyle düşüktür. Ancak bunun sebebi, Çerçeve Antlaşma ile belirlenen koşullardan daha azının ulusal mevzuatta benimsenmesi değil, Çerçeve Anlaşma ile korumanın sadece kendi öngördüğü düzenlemeler kapsamında sağlanmasına imkân verilmesidir. Kamanabrou, (n 91) 239.

130 İncelenen AB ülke kanunları arasında tek iktibas sorunu, azami sayı ve azami süre sınırını birbirinin alternatifi koşul olarak benimseyen Birleşik Krallık, İrlanda ve Malta kanunlarında tespit edilmiştir. Bu ülkelerin kanunlarında üst üste yapılan belirli süreli iş sözleşmelerinin azami sayısı belirlenmiş olup azami süresi her üç ülke mevzuatında da dört yıldır. ibid 232, 239.

131 ibid 231.

132 ibid 229.

133 ibid 230.

134 ibid 230-231.
} 
Aynı çalışmada, belirli süreli iş sözleşmesinin yenilenmesinde Çerçeve Antlaşma' da yer alan üç koşulu da benimseyen ülkelerin uyum bakımından daha iyi olduğuna ilişkin bir sonuca da ulaşılmamıştır. Almanya, Polonya ve Belçika kanunları bu kapsamda incelenmiştir. Bu ülkelerde birbirini takip eden belirli süreli işsözleşmeleri için azami süre ve azami sayı sınırı koşulu kümülatif olarak aranırken "objektif neden" koşulu ise bunların alternatifi olarak düzenlenmiştir. Bununla kastedilen, işveren iş̧ sözleşmesinin yenilenmesinde objektif nedene dayandığ takdirde azami bir süreye ve azami bir sayı sınırı koşulu aranmamakta; ancak objektif neden bulunmuyorsa süre ve sayı sınırlaması aranmaktadır ${ }^{135}$.

Görüldüğü üzere, hukukumuz bakımından İş Kanunu m. 11 hükmü dayanak düzenlemesi olan Çerçeve Antlaşma ile uyumlu olduğu gibi, uyum bakımından Avrupa Birliği üyesi ülkelerden geride de değildir. Ancak bu durum, uygulamada belirsizliklerin ortaya çıkmasına ve kanun hükmüne haklı eleştirilerin yöneltilmesine engel olamamıştır. Gerçekten de İş Kanunu m. 11 hükmünün lafzında belirli süreli iş sözleşmesinin ne kadar süre ve sayıda yenilenebileceğine ilişkin bir netliğin olmaması uygulamada belirli süreli iş sözleşmesini yenileme ihtiyacı içinde olan taraflar için öngörülemezlik yaratmaktadır. Kanaatimizce de bu durumun kanun değişikliği ile giderilmesi en doğru çözüm olacaktır. Hatta bu değişikliğin sadece İş Kanunu m. 11 hükmünde değil, bunun yanında diğer iş kanunları bakımından da uygulama bulan TBK hükmü için de öngörülmesi isabetli olacaktır.

Belirtelim ki, kanun değişikliği olmasa da hukukumuzda belirli süreli iş sözleşmesinin ilelebet yenilenmesini engelleyen mekanizmalar bulunmaktadır. Gerek hakkın kötüye kullanılması yasağı gerekse de kanun hükmünün amacı, belirli süreli iş sözleşmesinin yenilenmesi bakımından bir sınır getirmektedir. Hâkimin önüne gelen uyuşmazlıklarda, somut olayın özellikleri çerçevesinde, bunları da gözeterek sonuca ulaşması gerektiği kanaatindeyiz. Belirtelim ki, Yargıtay 9. Hukuk Dairesi’nin 2005 yılında verdiği karar önemli olmakla birlikte münferit kalmıştır ${ }^{136}$.

Alman Federal İş Mahkemesi'nin belirli süreli iş sözleşmesinin yenilenmesinde hakkın kötüye kullanılmasının ne zaman ortaya çıkacağına ilişkin detaylı değerlendirmeler yaptığı 2016 yılında verdiği $\operatorname{karar}^{137}$ bu sebeple dikkate değerdir. Öncelikle hatırlatalım ki, Alman Kısmi Süreli ve Belirli Süreli İş Sözleşmeleri Hakkında Kanun § 14 hükmüne göre, birbirini takip eden belirli süreli iş sözleşmeleri için azami süre iki yıl olup azami sayı ise üçtür. Yukarıda da belirtildiği üzere, kümülatif olarak benimsenen azami süre ve azami sayı sınırı koşulların alternatifi, objektif nedenin mevcudiyetidir. Dolayısıyla, Alman hukukunda da objektif nedene dayalı olarak belirli süreli iş sözleşmesinin yenilenmesinde kanun ile azami süre ve

\footnotetext{
135 ibid 231.

136 Yargıtay 9 HD, 12170/15792, 05.05.2005; karara ilişkin açıklamalar için bkz yukarıda IV, 3, a.

137 BAG, 7 AZR 135/15, 26.10.2016.
} 
azami sayı sınırı uygulanmadığından işverenin hakkını kötüye kullanması yine de söz konusu olabilmektedir.

Federal İş Mahkemesi'nin söz edilen karardaki değerlendirmeleri de işverenin objektif nedene dayalı olarak belirli süreli iş sözleşmesini yenilemesinde, kötüye kullanmanın ne zaman ortaya çıkacağına ilişkindir. Kararda, Federal İş Mahkemesi, belirli süreli iş sözleşmesinin yenilenerek kötüye kullanıldığının kabulü için üç aşamalı bir inceleme yapmıştır. İlk aşamada; aşağıdaki üç durumdan birinin varlığı tespit edilirse hakkın kötüye kullanıldığı kabul edilmekte ve ancak işverenin kötüye kullanma şüphesini geçersiz kılan özel durumunu ortaya koyması hâlinde belirli süreli iş sözleşmesinin yenilenmesine izin verilebilmektedir. Bu durumlar:

i. İş ilişkisinin toplamda 10 y1lı geçmiş olması,

ii. Belirli süreli iş sözleşmesinin 15 'ten fazla yapılmış olması,

iii. İş ilişkisinin 8 yılı geçmiş ve bu sürede 12'den fazla belirli süreli iş sözleşmesi yapılmış olmasıdır.

İlk aşamada bu durumlar tespit edilmediği takdirde ise, ikinci aşamaya geçilmektedir. $\mathrm{Bu}$ yeni aşamada, aşağıda yazılı üç duruma ilişkin tespit yapılmaktadır. Bunlardan birinin gerçekleşmesi hâlinde kapsamlı bir kötüye kullanım kontrolünün yapılacağına işaret edilmekte ve işçinin kötüye kullanımı ispatlaması gerekmektedir. Bu durumlar:

i. İş ilişsisinin toplamda 8 yılı geçmiş olması,

ii. Belirli süreli iş sözleşmesinin 12'den fazla yapılmış olması,

iii. İş ilişkisinin toplamda 6 yılı geçmiş ve bu sürede 9'dan fazla belirli süreli iş sözleşmesi yapılmış olmasıdır.

Bu durumlar tespit edilemediği takdirde ise, üçüncü aşamaya geçilmekte ve Federal İş Mahkemesi belirli süreli iş sözleşmelerinin yenilenmesine icazet vermektedir. Ancak incelenen kararda kötüye kullanmanın belirlenmesinde dikkate alınacak başka kriterlere de yer verilmiştir. Yüksek Mahkemeye göre bu kriterler şunlardır:

- Aynı işyerinde benzer işleri yapan belirsiz süreli iş sözleşmesi ile çalışan işçilerin olması,

- Belirli süreli iş sözleşmesinde belirlenen sürenin işverenin meşru yararının olmaksızın tekrar tekrar iş için tahmin edilen sürenin altında kalması,

- Belirsiz süreli iş sözleşmesi ihtimali varken devam eden belirli süreli iş sözleşmeleri,

- Belirli süreli iş ilişkilerinin birbirini takiben kesintisiz olarak sürekliliğidir. 
Hukukumuz bakımından değerlendirmeye devam edecek olursak İş Kanunu m. 11 hükmünde yapılacak değişikliğin belirli süreli iş sözleşmesinin yenilenmesinde objektif neden yanında süre ve sayı bakımından bir sınırlama yapılması doktrin ve Yargitay tarafindan ifade edilen uygulamadaki belirsizliklerin giderilmesi için en isabetli yol olduğunu tekrarlamak isteriz. Ancak mevcut düzenlemenin uygulanmasında da Federal İş Mahkemesi’nin anlatılan kararında olduğu gibi yargının uygulamaya yol gösterici ve hakkın kötüye kullanılması yasağını somutlaştıran kararlar vermesi beklentilerimiz arasındadır.

$\mathrm{Bu}$ çerçevede, yargı tarafından belirli süreli iş sözleşmesinin yenilenmesi bakımından TBK m. 430/3 hükmü dikkate alınması düşülebilir. Bu maddede yer verilen ve belirli süreli iş sözleşmesinin işçi tarafından süreli fesih yoluyla sona erdirilebileceğinin kabul edildiği sınır olan 10 yıllık sürenin aşılması ile, belirli süreli iş sözleşmesinin yenilenmesinde hakkın kötüye kullandığı sonucuna ulaşılabilir ${ }^{138}$. Aksini yani kötüye kullanma şüphesini geçersiz kılan özel durumunu işveren ispatladığı takdirde belirli süreli iş sözleşmesinin yenilenmesine izin verilebilir.

\section{Sonuç}

Türk hukukunda iş kanunları belirli süreli iş sözleşmesinin ilk defa yapılmasında ve yenilenmesinde farklı esaslar öngörmüştür. Belirli süreli iş sözleşmesinin ilk defa yapılması için aranan koşulların en katı olduğu kanun, 4857 sayılı İş Kanunu olup m. 11 hükmü ile sözleşmenin sürelendirilmesi “objektif neden” koşulunun varlığına bağlanmıştır. Bu koşula ilişkin tartışmalar ise, kanunun yapılış aşamasından bu yana, aralıksız devam etmektedir.

Kanaatimizce de, belirli süreli iş sözleşmesinin yapılmasında işçinin korunması ve işletmelerin esnekleşme ihtiyacı arasında denge gözetilerek objektif neden koşuluna ilişkin istisnalar öngörülebilir. Ancak kanun değişikliğinin yeni hukuki sorunları beraberinde getirmemesi gerekmektedir.

Oysa 5 Kasım 2020 tarihi itibariyle TBMM gündemine taşınan Torba Kanun Teklifi'ndeki belirli süreli iş sözleşmesinin yapılmasında ve yenilenmesinde belirli yaş grubundaki işçileri objektif neden koşulundan istisna kılan bir hükme yer vermekte idi. Bu hüküm, yaş ayırımcılığı yasağına aykırılık teşkil etmekte olup kanunlaşmamış olması isabetli olmuştur.

Belirli süreli iş sözleşmesinin yenilenmesi bakımından ise ilk defa yapılmasından farklı olarak, 4857 sayılı İş Kanunu ile diğer iş kanunlarında benzer esaslar benimsenmiştir. Gerçekten de, DİK kapsamındaki işçilerile BİK ve TBK kapsamındaki

$\overline{138}$ Görüşümüz, kanundan kaynaklanan belirli süreli iş sözleşmeler dışındaki belirli iş sözleşmelerinin yenilenmesine ilişkindir. 
işçiler, belirli süreli iş sözleşmesinin yenilenmesinde İş Kanunu kapsamındaki işçiler gibi "objektif neden" koşuluna tabidir.

Doktrin ve yarg1 tarafından belirli süreli iş sözleşmesinin yenilenmesi aranan objektifneden koşulu dişında da koşullaröngörülmesi önerilmiştir. Gerçekten de kanun hükmünün belirli süreli iş sözleşmesinin ne kadar ve sayıda yenilenebileceğine ilişkin bir netlik içermemesi uygulamada belirsizliklere sebep olmaktadır. Kanaatimizce kanunda yapılacak bir değişiklik ile belirli süreli iş sözleşmelerinin yenilenmesinde süre ve sayı sınırı getirilmesi, en isabetli çözüm olacaktır. Ancak bu değişikliğin sadece 4857 sayılı İş Kanunu değil, bunun yanında diğer iş kanunları bakımından da uygulama bulan TBK hükmü için de öngörülmesi daha isabetli olacaktır.

Bununla birlikte, mevcut düzenlemenin uygulanmasında da belirli süreli iş sözleşmesinin yenilenerek ilelebet sürmesini engelleyici mekanizmalar mevcut olup hakkın kötüye kullanılması yasağı ve normun amacı dikkate alınarak yarg1 tarafında sınırlamalar getirebileceğini düşünmekteyiz. Bu bağlamda TBK m. 430/3 hükmü dikkate alınarak toplam süresi 10 yılı aşan belirli süreli iş sözleşmelerinin hakkın kötüye kullanılması teşkil edeceği kabul edilebilir. Bu veya benzeri yönde değerlendirmeler ile uygulamada ortaya çıkan belirsizliklerin giderilmesi için yargının konuyu somutlaştıran kararlar vermesi beklentilerimiz arasındadır.

\footnotetext{
Hakem Değerlendirmesi: Dış bağımsız.

Çıkar Çatışması: Yazar çıkar çatışması bildirmemiştir.

Finansal Destek: Yazar bu çalışma için finansal destek almadığını beyan etmiştir.

Peer-review: Externally peer-reviewed.

Conflict of Interest: The author has no conflict of interest to declare.

Grant Support: The author declared that this study has received no financial support.
} 


\section{Bibliyografya/Bibliography}

Aksoy MU, 'Alman Kısmi Süreli Çalışma ve Belirli Süreli İş Sözleşmeleri Hakkında Yasa ve Çevirisi' (2014) 20(Özel Sayı) Marmara Üniversitesi Hukuk Fakültesi Hukuk Araştırmaları Dergisi (Prof. Dr. Ali Riza Okur'a Armağan) 1215-1236.

Akyiğit E, Bireysel İş Hukuku Dersleri (1. Bası, Seçkin 2020).

Alp M, 'Belirli Süreli İş Sözleşmesinin Yargıtay Tarafından Resen Belirsiz Süreli İş Sözleşmesinde Dönüştürülmesi' iç KD Yenisey (ed), Prof. Dr. Savaş Taşkent'e Armağan (On İki Levha 2019) 477-502.

Alp M, ‘İş İlişkisinin Sona Ermesi ve Kıdem Tazminatı Açısından Yargıtayın 2013 Yı1ı Kararlarının Değerlendirilmesi’ (2015) Yargitay’ın İş Hukuku ve Sosyal Güvenlik Hukuku Kararlarının Değerlendirilmesi 2013 sayfa aralığ (Değerlendirme).

Alpagut G, ‘4857 Sayılı Yasa Çerçevesinde Belirli Süreli Hizmet Sözleşmesi’ (2004) 43 Mercek Dergisi 73-92.

Alpagut G, 'AB’nde Güvenceli Esneklik ve Türkiye'deki Yasal Düzenlemeler' (2008) 1 TİSK Akademi 6-37.

Alpagut G, 'Türk Borçlar Kanununun Hizmet Sözleşmesinin Devri, Sona Ermesi, Rekabet Yasağ1, Cezai Şart ve İbranameye İlişkin Hükümleri’ (2011) 8 (31) Legal İHSGHD 913-960.

Alpagut G, Belirli Süreli Hizmet Sözleşmesi (1. Bas1, Mavi 1998).

Başbuğ A ve Yücel Bodur M, İş Hukuku (5. Bası, Beta 2018).

Başterzi S, ‘Avrupa Birliği Konseyinin 99/70 Sayılı Yönergesi Işı̆̆ında Belirli Süreli İş Sözleşmesi Yapma Koşulları ve 4857 Sayılı İş Kanununun Öngördüğü Sistem’ (2006) İş Hukuku ve Sosyal Güvenlik Hukuku Türk Milli Komitesi 30. Y1l Armağanı, 119-190.

Başterzi S, 'Belirli Süreli İş Sözleşmesinin Yapılmasına İlişkin Objektif Nedenlerin Tespitinde Menfaatler Dengesi İşçinin Haklı Menfaati' (2013) 15 (Özel Say1) DEÜHFD 423-450.

Başterzi S, 'İş İlişkisinin Kurulması, Hükümleri ve İşin Düzenlenmesi Açısından Yargıtayın 2009 Yılı Kararlarının Değerlendirilmesi’ (2011) Yargıtayın İş Hukuku ve Sosyal Güvenlik Hukuku Kararlarının Değerlendirilmesi 2009, 1-134.

Baycık G, 'İş İlişkisinin Kurulması, Hükümleri ve İşin Düzenlenmesi Açısından Yargıtayın 2016 Yılı Kararlarının Değerlendirilmesi’ (2018) Yargıtay’ın İş Hukuku ve Sosyal Güvenlik Hukuku Kararlarının Değerlendirilmesi 2016, 7-356

Bozkurt Gümrükçüoğlu Y, Türk Iş̧ Hukuku’nda Belirli Süreli İ̧s Sözleşmesi (1. Bası, Vedat 2012).

Bozkurt Gümrükçüoğlu Y ve Gemici Filiz B, 'Yargıtay Kararları Işı̆̆ında Özel Okul Öğretmenleri ile Yapılacak İş Sözleşmelerinin Türüne İlişkin Bir Değerlendirme’ (2016) 15 (1-2) İstanbul Kültür Üniversitesi Hukuk Fakültesi Dergisi 369-401.

Bozkurt Gümrükçüoğlu Y, '5580 Sayılı Özel Öğretim Kurumları Kanunu Kapsamında Yapılan Zincirleme İş Sözleşmesinin Sona Ermesinde Kıdem Tazminatı' (2016) 74 (Özel Sayı) İstanbul Üniversitesi Hukuk Fakültesi Mecmuası (Prof. Dr. Fevzi Şahlanan’a Armağan) 223-249.

Canbolat T, 'Mevzuatta Öngörülen Bazı İş Sözleşmesi Türlerinin 4857 sayılı İş Kanununun Belirli Süreli İş Sözleşmesine İlişkin Esasları Yönünden Değerlendirilmesi’(2007) 4 (13) Legal İHSGHD 187-220.

Caniklioğlu N, 'İş Kanununun 10. Yılında Belirli Süreli İş Sözleşmesi ile Kısmi Süreli İş Sözleşmesi ve Uygulamada Yaşanan Sorunlar’ (2016) 10. Yılında 4857 Sayılı İş Kanunu (Uygulama Sorunları ve Çözüm Önerileri) Sempozyumu, Ankara Yıldırım Beyazıt Üniversitesi Hukuk Fakültesi-Çelik İş Sendikası. 
Caniklioğlu N, 'Türk Borçlar Kanununun Hizmet Sözleşmesinin Kurulmasına, Tarafların Hak ve Borçlarına İlişkin Hükümlerinin Genel Bir Değerlendirilmesi' (2012) Çalışma Hayatı Açısından Yeni Borçlar Kanunu ve Ticaret Kanunu Semineri, 20-21 Eylül 2011, Türkiye İşveren Sendikaları Konfederasyonu, 78-109.

Centel T, Introduction to Turkish Labaur Law (1 st edn, Springer 2017).

Centel T, ‘Özel Okul Öğretmeniyle Sözleşme Yapılması' (2007) 6 Sicil Dergisi 22-26.

Çelik N, Caniklioğlu N ve Canbolat T, İş Hukuku Dersleri (33. Bası, Beta 2020).

Däubler W und Bertzbach M (Hrsg), Allgemeines Gleichbehandlungsgesetz: Handkommentar (Nomos 2013).

Deutsche Welle Türkiye, 'Torba Yasa Tartışması: Kıdem Tazminatı ve Emeklilik Hakkı Tehlikede' (01.11.2020) < https://www.dw.com/tr/torba-yasa-tartışması-kıdem-tazminat1-ve-emeklilikhakk1-tehlikede/a-55455034 > Erişim Tarihi 15 Aralık 2020.

Doğan Yenisey K, 'Hizmet Sözleşmesi' iç Murat İnceoğlu (ed) Türk Borçlar Kanunu Sempozyumu (On İki Levha, 2012) 297-336.

Doğan Yenisey K, 'İşverenin Sözleşmenin Feshinde Eşit Davranma Borcuna İlişkin İki Yargıtay Kararının Düşündürdükleri' (2006) 2 Sicil Dergisi 60-65.

Doğan Yenisey K, İş Hukukunun Emredici Yapısı (1. Bası, Beta 2014).

Ekmekçi Ö ve Yiğit E, Bireysel İş Hukuku Dersleri (1. Bası, On İki Levha 2020).

Ekonomi M, '4857 Sayılı Kanun Hükümlerine Göre Belirli Süreli İş Sözleşmesinin Hukuka Uygunluğu (I) Kavram Süre ve Yenileme’ (2006) 3 (9) Legal İHSGHD 15-32.

Eyrenci Ö, Taşkent S ve Ulucan D, Bireysel İş Hukuku (10. Bas1, Beta 2020).

Güler M, 'Belirli Süreli İş Sözleşmesi’ (2005) 2 (5) Legal İHSGHD 27-82.

Güneş B ve Mutlay FB, 'Yeni Borçlar Kanununun 'Genel Hizmet Sözleşmesi'ne İlişkin Hükümlerinin İş Kanunu ve 818 Sayılı Kanunla Karşılaştırılarak Değerlendirilmesi’ (2011) 30 (3) Çalışma ve Toplum Dergisi 231-288.

Güven E ve Aydın U, Bireysel İş Hukuku (6. Bası, Nisan 2020).

Güzel A, 'Bireysel İş İlişkisinin Kurulması, Hükümleri ve İşin Düzenlenmesi' (2007) Yargıtay’ın İş Hukuku ve Sosyal Güvenlik Hukuku Kararlarının Değerlendirilmesi 2005, 11-74.

Güzel A ve Ertan E, 'Avrupa Birliği Hukukunda ve Özellikle Avrupa Toplulukları Adalet Divanı (ATAD) Kararlarında Belirli Süreli İş Sözleşmesinin Yapılması ve Yenilenme Koşulları’ (2008) 5 (18) Legal İHSGHD 395-416.

Güzel A, Özkaraca E ve Ugan D, 'Karşılaştırmalı Hukukta ve Türk Hukukunda Belirli Süreli İş Sözleşmesi: Yapılma ve Yenilenme Koşulları' iç Süleyman Başterzi (ed) Prof. Dr. Sarper Süzek'e Armağan C. 1 (Beta 2011) 475-566.

İnceoğlu S, 'Türk Anayasa Mahkemesi ve İnsan Hakları Avrupa Mahkemesi Kararlarında Eşitlik ve Ayrımcılık Yasağı’ (2006) 11 (4) Çalışma ve Toplum Dergisi 45-62.

Kabakçı M, 'Belirli Süreli İş Sözleşmesinin Geçersizliğinin İşçi ve İşveren Açısından Farklı Değerlendirilmesi Gereği' (2014) 72 (2) İ̈̈HFD (Prof. Dr. Berin Ergin'e Armağan) 123-141.

Kamanabrou S, 'Successful Rules on Successive Fixed-Term Contracts?' (2017) 33 (2) International Journal of Comparative Labour Law and Industrial Relations 221-240.

Keser H, 'Objektif Sebep Olmaksızın Yapılan Belirli Süreli İş Sözleşmesinde Düzenlenmiş Cezai Şartın Geçerliliğinin Yargıtay İçtihadı Birleştirme Büyük Genel Kurulu Kararı Kapsamında Değerlendirilmesi' (2020) 43 Sicil Dergisi 30-52. 
Krebber S, 'The Social Rights Approach of the European Court of Justice to Enforce European Employment Law’ (2006) 27 (3) Comparative Labor Law \& Policy Journal, 377-403.

Metin Y, Ölçülülük İlkesi, Karşılaştırmalı Bir Anayasa Hukuku İncelemesi (1. Bası, Seçkin 2002).

Mollamahmutoğlu H, Astarlı M ve Baysal U, İş Hukuku Ders Kitabı Cilt 1: Bireysel İş Hukuku, (4. Bas1, Lykeion 2020).

Narmanlığlu Ü, 'Belirli Süreli İş Sözleşmesini Sona Erdiren Olgular ve İşlemler' (2012) 9 (35) Legal İHSGHD 3-24.

Sädevirta M, A Comparative Study of the Regulation Governing the Use of Fixed-Term Contracts in Three EU Member States (1st edn, Unigrafia 2013).

Senyen Kaplan ET, ‘Belirli Süreli İş Sözleşmesinin Haksız Feshinin Hüküm ve Sonuçları’ (2016) 36 Sicil Dergisi 17-32.

Soyer P, ‘6098 Sayılı Türk Borçlar Kanunu'nda Yer Alan 'Genel Hizmet Sözleşmesi’ne İlişkin 'Bazı' Hükümlerin İş Hukuku Açısından Önemi' (2012) İş Hukukunda Güncel Sorunlar 2, 25 May1s 2012, 1-52.

Soyer P, 'Hizmet Sözleşmesinin Sona Ermesine İlişkin 'Yeni' Türk Borçlar Kanunu Hükümleri ve İş Hukuku Bakımından Önemi’ (2011) 22 Sicil Dergisi 12-21.

Sümer HH, ‘Özel Öğretim Kurumu Öğretmenlerinin İş Sözleşmelerinin Hukuki Niteliği’ (2016) 15 (1-1) İstanbul Kültür Üniversitesi Hukuk Fakültesi Dergisi 407-441.

Sümer HH, İş Hukuku Uygulamaları (7. Bası, Seçkin 2019).

Süzek S, Işs Hukuku (20. Bası, Beta 2020).

Şahin Emir A, 'Belirli Süreli İş Sözleşmesine İlişkin Sınırlamalar ve Esneklik Olanakları Avrupa Birliği Örnekleriyle’ (2016) 18 (1) DEÜHFD 113-153.

Taşkent S, 'Belirli Süreli İş Sözleşmelerinde “Esaslı Neden” Sorunu' (2011) 24 Sicil Dergisi 19-30.

Tuncay C, 'İş İlişkisinin Kurulması, Hükümleri ve İşin Düzenlenmesi Açısından Yargıtayın 2011 Yılı Kararlarının Değerlendirilmesi' (2013) Yargıtayın İş Hukuku ve Sosyal Güvenlik Hukuku Kararlarının Değerlendirilmesi 2011, 1-98.

Ugan Çatalkaya D, İş Hukukunda Ölçülülük İlkesi (1. Bas1, Beta 2019).

Ulucan D, ‘4857 Sayılı Kanunu Göre İş Sözleşmesi Türleri’ (2003) Yeni İş Yasas1, 25-29 Haziran 2003, Toprak, Seramik, Çimento ve Cam Sanayi İşyerleri Sendikası Yayını, 35-65.

Uşan F ve Erdoğan C, İş ve Sosyal Güvenlik Hukuku (1. Bas1, Seçkin 2020).

Ünal C, İş Hukukunda Yaş Ayırımcılığı (1. Bası, On İki Levha 2018).

Yayvak Namlı İ, İş Hukuku’nda Cezai Şart (1. Bası, On İki Levha 2019).

Yıldız GB, 'Güvenceli Esneklik ve 4857 Sayılı İş Kanunu', iç Süleyman Başterzi (ed) Prof. Dr. Sarper Süzek'e Armağan C. 1 (Beta 2011) 203-231.

Yiğit Y, 'Belirli Süreli İş Sözleşmesi Yapma Serbestisi ve Bu Serbestinin Sınırları' (2012) 14 (2) DEÜHFD 101-166. 
